\title{
Diversity in obsidian use in the prehistoric and early historic Middle East
}

DOI:

10.1016/j.quaint.2017.09.023

Document Version

Accepted author manuscript

Link to publication record in Manchester Research Explorer

\section{Citation for published version (APA):}

Campbell, S., \& Healey, E. (2018). Diversity in obsidian use in the prehistoric and early historic Middle East.

Quaternary International, 468, 141-154. https://doi.org/10.1016/j.quaint.2017.09.023

\section{Published in:}

Quaternary International

\section{Citing this paper}

Please note that where the full-text provided on Manchester Research Explorer is the Author Accepted Manuscript or Proof version this may differ from the final Published version. If citing, it is advised that you check and use the publisher's definitive version.

\section{General rights}

Copyright and moral rights for the publications made accessible in the Research Explorer are retained by the authors and/or other copyright owners and it is a condition of accessing publications that users recognise and abide by the legal requirements associated with these rights.

\section{Takedown policy}

If you believe that this document breaches copyright please refer to the University of Manchester's Takedown Procedures [http://man.ac.uk/04Y6Bo] or contact uml.scholarlycommunications@manchester.ac.uk providing relevant details, so we can investigate your claim.

\section{OPEN ACCESS}




\title{
Diversity in obsidian use in the prehistoric and early historic Middle East
}

\author{
Stuart Campbell and Elizabeth Healey
}

\begin{abstract}
The presence of obsidian in the Near East has always evoked a response about its exotic nature and origins. It was not until 1960s, however, that this was put onto a scientific footing when Colin Renfrew and his collaborators began to explore obsidian in Turkey and the Mediterranean. Their characterisation of the sources allowed them to attribute artefacts to different sources and suggest models of dispersal and distribution. Since then considerably more artefacts have been attributed to sources, although mostly only small numbers from individual sites; this has led to various interpretations of how obsidian was obtained and used; new studies have considered least cost path analysis, network analysis and agent based modelling. Increasingly, new methods of provenancing of artefacts have also meant that large number of artefacts can be analysed relatively speedily and efficiently. Portable instruments allow data to be collected outside laboratories, avoiding restrictions imposed by export licenses or simplifying work on museum collections. Here we employ richness and diversity indexes to elucidate some of the patterns in obsidian source use and argue that there are several reasons why the provenancing of large proportions of assemblages will be critical in exploiting the true potential of obsidian studies in the Near East, even though the initial haphazard, small sample approach has been quite effective in sketching out the big picture.
\end{abstract}

\section{Key Words}

Obsidian; pXRF; Middle East; provenance studies; large assemblages, richness and diversity indexes

\section{Introduction}

In the Middle East obsidian only occurs naturally in certain regions but it was widely used to make tools from early prehistory. In the earlier Palaeolithic, that use was only near to source (Kuhn et al., 2015; Yalçınca, 1998) but, ca. 40,000 years ago, it began to be acquired by people far from the sources, something which intensified through time (Frahm and Hauck, 2017). As a raw material, it is sufficiently distinctive in appearance to be easily recognized as an exotic material so is likely to have been as attractive to prehistoric peoples as to modern archaeologists, albeit for different reasons. 
For archaeologists, the possibility of being able to match the obsidian used to make tools to its geological source offers many interpretative possibilities, including exchange systems, social networks and symbolic meanings. We should remember, too, that prehistoric people might have been, at least on some occasions, aware of the distant origin of the material they exploited and this may also have been an influence on the way that its meaning was constructed (Maeda, 2003, 2009: 144, 150, 153, 2013: 269ff.; Carter et al., 2013).

Our understanding of which sources were important depends almost entirely on artefacts which have been provenanced from excavated sites which are mostly far from the sources. There is very little evidence for occupation at the sources themselves after the Middle Palaeolithic, apart from some workshops and campsites on the Göllüdağ source (Balkan-Atlı et al., 2013: 468).

The most systematic overview remains that of Christine Chataigner (1998), which built on and consolidated Renfrew et al.'s $(1966,1968)$ work, even though much more obsidian has now been analysed. It indicated that a very high proportion of the obsidian provenanced comes from three compositionally distinct sources, namely Göllüdağ East, the peralkaline sources of Nemrut Dağ/Bingöl A (which although $150 \mathrm{~km}$ apart have proved difficult to distinguish compositionally) and the calcalkaline source at Bingöl B with other sources playing a lesser and sometimes very minor role. While Nemrut Dağ and Bingöl A are now generally distinguishable (Chataigner, 1994; Frahm, 2012a; Carter et al., 2013), the essential pattern remains the same, with a very limited set of sources apparently dominating the supply of obsidian. However, as Chataigner herself pointed out (1998: 322 ), this overview was based on a small number of artefacts from each assemblage relative to the numbers excavated so it has probably underestimated the number of secondary sources present. It is also a picture that has often been based around the site as the primary unit of analysis, when most sites have long periods of occupation and potential variation in specific phases and sub-contexts (already implicit in the phasing in the tables in Chataigner 1998). Now, however, advances in analytical techniques (e.g., Poupeau et al., 2007; Carter, 2014; Forster and Grave, 2012; Frahm, 2013) make it increasingly feasible to provenance many artefacts from single assemblages (or even entire assemblages) and to link techno-morphological attributes to provenance data in a way that has hitherto not been possible (e.g., Maeda, 2013; Carter et al., 2014; Milić, 2014; Campbell and Healey, 2016). This starts to change our approach to understanding obsidian use in the past.

\section{Background to this study}

\subsection{The sources}

The geological occurrences of obsidian in the Middle East that are of particular importance in this article are concentrated in three main regions central Anatolia, south-east Anatolia, and north-east Anatolia, Armenia and Georgia (Fig. 1). The large majority of obsidian found in Mesopotamia and the 
Levant originates from sources in mountainous regions of central Anatolia and south-east Anatolia. Obsidian from sources further afield to the north and east is only rarely present. While geological sources of obsidian can also be found in the south-west of the Arabian Peninsula and East Africa, and in the north-west Anatolian, Mediterranean and Carpathian regions, the use of these sources of obsidian is not documented in most of the Middle East.

Behind this apparently straightforward picture, the reality is much more complex. Our knowledge of specific source areas is still quite variable. Recent geological and geophysical surveys of Göllüdag (Binder et al., 2011), Nemrut Dağ (Robin et al., 2015; Robin et al., 2016), north-east Anatolia (Chataigner and Gratuze 2014a, 2014b; see http://geobs.univ-rouen.fr/; Akköprü et al., 2017), Meydan Dağ and elsewhere by the McMaster Obsidian Procurement Expedition (see https://maxlab.mcmaster.ca/research-projects/mcmaster-obsidian-procurement-expedition-mope), as well as Biagi and Gratuze's survey of Paravani /Chikiani in Georgia (Biagi and Gratuze, 2016), demonstrate that the physical availability of obsidian as well as its elemental composition is often considerably more complicated than initially appreciated (cf., Shackley, 2008; Poupeau et al., 2005; Binder et al., 2011; Robin et al., 2016). In many cases, it is clear that the locations from which people obtained obsidian in the past were the geological outcrops themselves, as the quarry workshops at the Göllüdağ source indicate (Binder et al., 2011), but in other cases obsidian was probably mainly obtained from secondary sources such as river beds.

\subsection{Source characterisation and geo-referenced data sets}

As our knowledge of the complexity of the sources increases, successful attribution of artefacts to source obviously depends on the availability of an up-to-date and comprehensive geo-referenced library. In the main, the most used sources are better documented and are represented in most reference collections of source material. In some cases, the compositions of the major sources are very distinctive and can be identified with reasonable certainty from published data. For example, Bingöl B does not overlap with other compositional groups across many elements, while the peralkaline obsidians of Bingöl A and Nemrut Dağ cannot easily be confused with other sources. In other cases, the distinction can be more problematic. The composition of Göllüdağ East obsidian is less easily distinguished from obsidian from Armenian sources such as Syunik, unless the analyst has access to source material from both areas. In the Levant and Mesopotamia, this may appear to be a peripheral problem, as Göllüdağ East is very common and Armenian obsidian extremely rare in prehistory but, as discussed below, in later Mesopotamia at least, Syunik does become significant as a source. When it is important to understand less common sources it becomes significant that they are both less well represented in reference collections and also less well documented in publications. This situation is gradually changing, with detailed studies of new obsidian source areas noted above, but progress remains slow and patchy. Attribution of artefacts to particular sources 
from older publications sometimes remains problematic, with misattributions to sources that were inadequately understood (e.g., Frahm et al., 2016) or the attribution of artefacts to, at the time, unknown sources. Unfortunately changes in techniques and limited use of international standards can make it difficult to solve these problems in retrospect. At the same time, obsidian source analysis is becoming more accessible, especially through the widespread use of portable X-ray Fluorescence (pXRF) instruments. While this brings many advantages (e.g., Frahm, 2013; Frahm et al. 2014), without empirical calibration to standards it can be easy to generate poor quality results that rely too heavily on published source data rather than using a comprehensive source data set analysed with the same instrumental setup (Nazaroff et al., 2010; Speakman and Shackley, 2013; Wilke, 2017). While attributions to the more common sources are overwhelmingly reliable, in both legacy data and some recent studies, artefacts from the less common sources may be underrepresented, which will impact our interpretation of the use of minor sources.

\subsection{Access to the sources and obsidian acquisition}

The mechanisms of the dispersal of obsidian from the sources has been a topic of discussion since Renfrew's seminal work in the 1960s and 1970s (Renfrew et al., 1968; Renfrew, 1975, 1977). He modelled distribution on the basis of quantity and distance from source, and his supply and falloff zones still provide the vocabulary for many discussions of obsidian exchange. While some elements of Renfrew's model still remain valid, despite the limited data, where studies have considered the form in which the obsidian reached a site and how it was worked, a more nuanced picture emerges. At Çatalhöyük, for example, two different modes have been noted, one in which quarry flakes were collected from no longer active workshops on Göllüdağ and taken back to site for working; the other in which obsidian from active workshops was reduced at the workshop prior to export (Carter and Milić, 2013a, 2013b). So too at Körtik Tepe in the Upper Tigris region, between 125 and $140 \mathrm{~km}$ from the nearest sources, the obsidian from Nemrut Dağ and Bingöl A was acquired as unmodified nodules, whereas that from Bingöl B was partly prepared before 'export' to Körtik Tepe (Carter et al., 2013: 561). Later at Tell Hamoukar, in northern Syria, unworked nodules from the Bingöl source area were present along with a full chaîne opératoire relating to blade production suggested direct access to the source (Khalidi et al., 2009: 891). In the case of a parcel of blades found at Tell Sabi Abyad, some $300 \mathrm{~km}$ distant from the source, Laurence Astruc et al. (2007) have offered two models of acquisition and dispersal both based on direct access to the source but with different ways of reaching the end location.

Other approaches have used formal modelling. One, in Armenia where multiple sources are potentially accessible, used travel costs and isochrones around the source with least cost path analysis to investigate potential routeways and the time needed to reach them. This has shown that 
the nearest source was not necessarily the preferred one (Chataigner and Barge, 2008). Although it can be a useful tool in investigating relative distances in geographical terms, least cost path analysis only considers a very limited set of physical parameters, potentially very different from the way people live and behave; other factors such as vegetation, time of year, family and social connections and significant features in the landscape cannot be ignored (Cummins and Johnston, 2007; Supernant, 2017; see also Section 3.1 below).

Small world network analysis provides a different approach. It has been used to explore the uneven distribution of obsidian to Pre-Pottery Neolithic B (PPNB) communities in the Levant based on distance from the nearest source and the amount of obsidian present, but not its origin. This is promising in that it suggests that some communities can get more direct access to the supplier than others and more complex networks, which include the possibility of multiple sources being involved, are being investigated (Ortega et al., 2014; Ibáñez et al., 2015; Ortega et al., 2016; Ibáñez et al., 2016).

The possible role of pastoral nomads in the distribution of obsidian from sources in south-east Anatolia has also been noted (e.g., Crawford, 1978; Chataigner, 1998: 308; Frahm and Feinberg, 2013a) and ethnographic studies of migration routes of twentieth century AD transhumant nomads may indeed mirror obsidian distribution patterns (Frahm and Feinberg, 2013a: Fig. 10). Indeed at Tell Hamoukar, the presence of raw nodules from the Bingöl region may indicate direct access to the source, perhaps through semi-sedentary people who incorporated both Bingöl and Hamoukar in their seasonal cycle (Khalidi et al., 2009: 891). Anthropological studies of expeditions to source areas more generally emphasise not only questions surrounding ownership and regulation of quarries, but also that extraction is frequently surrounded by, taboos, rituals, traditions and protocols (e.g., Tacon, 1991; Cooney, 1998; Stout, 2002; Robinson, 2004: 97; Topping and Lynott, 2005 and papers therein; Brumm, 2010), factors which are difficult to model.

Access to source must have been affected by multiple factors including distance, the complexity of the source distribution in a particular region, the type of terrain to be crossed and travel time, as well as seasonal conditions (e.g., most sources are snow covered for large parts of the year). Social networks and the political landscape undoubtedly also played a role.

However, most of these approaches have depended on the provenance analysis of a small number of artefacts and usually a small proportion of the assemblage. In this paper, we investigate the possible outcomes when many more artefacts are provenanced and use richness and diversity indexes to bring new perspectives to the acquisition and use of obsidian.

\subsection{The assemblages}


Although much of our knowledge of the exploitation of each source depends on the geochemical analysis of small samples of artefacts, initial attempts to engage with complete site assemblages were approached by grouping entire assemblages according to visual characteristics. In the Middle East, green obsidian almost always comes from the peralkaline sources of Bingöl A and Nemrut Dağ. Thus, Renfrew compared the use of green to grey obsidian at Tell Shimshara, Jarmo and sites in the Deh Luran Plain (Renfrew, 1969, 1970, 1977). Others have grouped obsidian assemblages according to its visual characteristics and tested the validity of the groups by sampling with geochemical analysis (Healey, 2000; Maeda, 2003; Healey and Campbell, 2009; Milić et al., 2013). Visual characterisation remains useful for an initial overview and in separating secondary sources from primary ones (Kobayashi, 2006) and has been employed following a strict protocol at Çatalhöyük to cope with 10,000s of artefacts where sources have been shown to be visually distinctive and limited in range (Milić et al., 2013). In some cases, it may indicate a deliberate choice of certain obsidians (Section 3.2 below).

With increased availability of non-destructive or near non-destructive methods and growing use of portable instruments it is now possible to characterise large proportions of, or even entire, assemblages. This brings new perspectives on how sources were exploited as well as raising questions about the comparability of provenance analysis of large and small data sets.

Large sample sizes significantly increase the range of interpretations of obsidian acquisition and use that can be explored. This is not simply related to overall sample size but because samples are inherently non-unitary. Older approaches often took the site as the key analytical unit. The key areas of interpretation were the date of the site, the percentage of chipped stone made of obsidian at that site and the sources exploited. Sometimes this is appropriate, and has remained a mainstay of recent approaches using network analysis and indeed is used later in this article. However, sites contain different chronological phases and each phase may be composed of multiple contexts, depending on the extent of excavation and how contexts are defined. Assemblages of obsidian also need to be considered as products of technological processes designed to produce different types of artefact rather than as static units. Analyses focussing on production, style and function need to consider multiple sub-divisions, all of which may be relevant to understand the use of a particular material.

The benefits of these approaches can be illustrated by a number of examples. In the Rouj Basin (Maeda, 2003: 181-182, 2009), the majority of the obsidian was obtained from Cappadocian sources during the late PPNB and early Ceramic Neolithic phases (ca. 7000 cal BC) but there is a significant switch to eastern sources at Tell Aray I between Rouj 2c and 3 periods (i.e. in the Halaf, ca. 60005400 cal BC) suggesting a change in obsidian supply, although the same technological practices were 
maintained. At Çatalhöyük, a gradual change both in technology and source choice has been demonstrated during the occupation of the site (Carter and Milić, 2013a, Fig. 21.2; Carter and Milić, 2013b). At Pre-Pottery Neolithic A (PPNA) Körtik Tepe in the Upper Tigris region, the larger sample size demonstrated that obsidian from Bingöl B was acquired in a different form to that from other sources, although once at site all were treated similarly (Carter et al., 2013). At Kenan Tepe, Group $3 \mathrm{~d}$ obsidian appears to have been acquired in a raw state and worked using different techniques from the other obsidians present, as well as with a nuanced pattern of change over relatively short periods of time (Campbell and Healey, 2016).

In contrast to research carried out in the Americas or Japan, this level of analysis of large assemblages is still in its infancy for Middle Eastern assemblages (Frahm, 2012c). The examples cited above are distinctive because they remain atypical. In future, provenancing of large proportions of assemblages will be increasingly significant in exploiting the true potential of obsidian studies in the Middle East. However, while larger sample sizes may be inherently desirable, it remains the case that many sites will remain represented by small samples. The amount of obsidian at some sites is simply very low, or the excavated area is small. Sites with legacy data from small samples will often remain important. Our approaches need to be sufficiently flexible to combine the different types of data.

At most sites in the Middle East, the majority of the obsidian comes from a very restricted range of sources but at many of these sites small quantities of obsidian from a much wider range of sources are also present. On the one hand, we need to understand the majority sources that make up the bulk of the assemblages at individual sites, while at the same time balancing this with an understanding of the small minority of obsidian that comes from the more rarely used sources. We would argue that these have complementary value in providing insights into different aspects of obsidian use in the past and suggest that richness and diversity indexes may be a useful way of elucidating this.

\section{Methodology}

The analysis in this article is based on two main sets of data. One is the increasing number of published provenance analyses of obsidian artefacts. The second is preliminary data from the evolving set of analyses being carried out in the Manchester Obsidian Laboratory (MOL) by the authors at the University of Manchester. A feature of both these data sets is that more recent work is starting to analyse large samples, and sometimes almost entire assemblages. Published examples include artefacts from Çatalhöyük (Carter and Milić, 2013a), Körtik Tepe (Carter et al., 2013), Abu Hureyra (Carter et al., 2012), Tell Aswad 1 (Orange et al., 2013), Qdeir 1 (Orange et al., 2013), the 
Rouj Basin (Maeda, 2003; Maeda, 2009), Tell Labwe south (Khalidi et al., 2013), Tell Mozan (Frahm, 2010) and Sos Höyük (Kobayashi, 2006).

The analyses of large data sets in the Manchester Obsidian Laboratory is ongoing or in course of publication and the results that we use here are preliminary. Here we draw on the analysis of 675 artefacts from Umm Dabaghiyah, 509 artefacts from Jericho, and 432 artefacts from Domuztepe (the most recent summary of which is in Frahm et al., 2016) as well as 822 artefacts from Kenan Tepe (Campbell and Healey, 2016). These analyses were undertaken using a portable Niton XL3t980 Goldd+ instrument to conduct ED-XRF. Details of the procedure are described in Campbell and Healey, 2016. In brief, each artefact is read for 90 seconds in the test stand using the instrument mining mode $(\mathrm{Cu} / \mathrm{Zn})$, which utilises an internal fundamental parameters calibration. Following a further empirical calibration against a set of international standards, this data is compared to that obtained for 1209 geo-referenced source samples for which the composition has been established using the same method, version 3.4 of the MOL source reference set. This collection of source samples has benefitted enormously from access to the collection built up by Akihiko Mochizuchi and Katsuji Kobayashi (Kobayashi and Mochizuki, 2007; Kobayashi and Sagona, 2007), in addition to the generosity of several other collaborators. While there remain areas in which we certainly require more extensive samples, this source database has helped us to attribute obsidian to less common and less predictable sources. For the artefacts, techno-morphological type and completeness are also recorded, as are the length, width, thickness and weight. The physical characteristics of the obsidian such as the presence of cortex (or weathered outer surfaces), texture and colour in transmitted light is also documented and each one photographed.

\subsection{Measuring diversity}

In the analysis of Middle Eastern obsidian, beyond a general awareness that increasing sample size increases the probability of getting a representative sample (Shackley, 2008), little attention has been given to the optimum proportion of an assemblage that should be included in provenance analysis to capture the full diversity. Chataigner suggested that about 20 artefacts need to be analysed to get a realistic idea of the sources used (Chataigner, 1998: 322). Others have recommended that $60 \%$ of an assemblage needs to be characterized to apportion the obsidian to the sources at a $95 \%$ level of confidence (Blackman et al., 1993). Elsewhere sampling has been hierarchical, nesting different approaches (Milić et al., 2013; Orange et al., 2017).

Measures of diversity in archaeological assemblages have a long and complex history (Orton, 2000: 171-176; Baxter, 2003: 236-243). Many of the approaches have drawn on research in ecology, examining species diversity in specific habitats and diversity indexes have been used in a wide range of fields of archaeology (e.g., Stark et al., 1982; Rhode, 1988; Kandler and Laland, 2009; Eren et al., 
2016). There has been some use with obsidian, but to date mainly in the Americas (e.g., Eerkens and Spurling, 2008; Scheiber et al., 2011). Different measures of diversity are available, although with very different characteristics. None are perfect and an informed choice needs to be made. However, it is often helpful that different ways of measuring diversity can emphasise different aspects of diversity and the way in which they are impacted by very different sample sizes.

Studies of diversity have emphasised two different aspects that can be measured, richness and evenness. Richness relates to the range of sources present within an assemblage. Evenness relates to the balance between the different sources, so takes frequency of occurrence into account. An assemblage in which material is more evenly distributed amongst a range of classes can be considered more diverse than one in which it is concentrated in a very limited group of classes, even if a much wider group of classes are present in very small numbers. Both aspects are relevant to understanding the role of obsidian in the past.

Richness can be most simply represented by a count of the number of categories or classes in a sample, sometimes referred to as class richness (Eren et al., 2016). However, it is immediately distorted by the extent to which the classes are differentiated (Kintigh, 1989: 26). This is a specific problem in obsidian analysis because we know that not all classes, in this case the obsidian source groups, are equally distinct. Some, like Göllüdağ East and West, are chemically distinct but geographically close. Others can be sources that are geographically distinct but have not always been separated in analysis. Most significantly, the important sources Bingöl A and Nemrut Dağ were often not distinguishable in the past. Even now, although they can usually be distinguished (e.g., Frahm, 2012; Orange et al., 2013; Carter et al., 2013; Robin et al., 2016), there are individual artefacts that remain ambiguous. Yet other source areas have complex eruptive histories making precise separation of sub-sources difficult (e.g., Gratuze, 1987; Cauvin et al., 1991; Biagi and Gratuze, 2016). And some sources remain unlocated, although clearly attested in the archaeological record. To make it more complicated, exploitation in the past can sometimes be from secondary deposits, such as river beds, rather than primary flows. Furthermore, access to individual flows within a single area may have been approached through different routes and negotiated through different social groups, giving distinct meanings to sources that we may now consider a single group. Decisions in contemporary archaeological studies about what constitutes a source will inevitably be arbitrary and may be misleading and lead to different interpretations of diversity.

A simple richness index, based on the count of different classes that are present in a sample, is also heavily impacted by sample size and small numbers will routinely underestimate the true richness of an assemblage. One simple way of dealing with this effect is to sample to redundancy by increasing the sample size to the point at which no more obsidian sources are encountered. In practice, this will 
be very difficult to achieve, not least because samples sizes are often limited by practical factors such as extent of excavation and laboratory time. In terms of site assemblages, at least, we may be approaching redundancy with some of the larger sample sizes that are available. In the Manchester analysis of Umm Dabaghiyah obsidian, we analysed 675 artefacts (ca. $80 \%$ of the recorded obsidian from the site) and only recorded the use of five sources of obsidian. This is probably quite close to the full range of obsidian sources exploited at this site. However, it is important to note that the fifth obsidian source only appeared with the $515^{\text {th }}$ artefact to be analysed. At Kenan Tepe, the final new source was identified in the $574^{\text {th }}$ artefact in a sample of 882 (which constituted ca. $50 \%$ of the entire assemblage; Campbell and Healey, 2016). Therefore, even when we are analysing very large quantities of obsidian that start to approach the total excavated assemblage, the sample sizes may approach the level of redundancy but probably not actually reach it.

An alternative approach has been to estimate the number of classes that may be unrepresented in a sample. This has been done in both archaeological (e.g., Eren et al., 2016) and ecological contexts using the Chao 1 estimator (Chao, 1984). Where any classes in a sample are represented by a single example (a singleton), an estimate of missing classes is calculated by counting the number of classes with a single or double occurrence (a doubleton). This is added to the observed richness as an approximation of the number of undetected classes that might be present in a complete assemblage. Where no classes are represented by a singleton, the observed richness is considered roughly correct.

Several approaches have been used to measure the evenness of a sample. The Shannon index of diversity (also referred to as Shannon-Weiner's index) has perhaps been the most common (Orton, 2000: 237; Chao et al., 2014). An assemblage where only a single class of obsidian is found would have a Shannon's index of zero, with increasingly large values corresponding to increasing diversity. This index is heavily influenced by the frequency with which classes occur, so it is a good measure of the number of common sources in use at a site. Simpson's index of diversity shares similar characteristics (Orton, 2000: 237; Chao et al., 2014), in that it places more emphasis on the major classes that are present and the evenness of the distribution between them, and correspondingly tends to discount the influence of rare sources. This also means that both indexes are less influenced by smaller sample sizes that do not approach redundancy. In the form of Simpson's index of diversity used here, zero again corresponds to the presence of only a single class of obsidian, while one is the maximum value, where obsidian is divided exactly evenly between several classes.

In this context, these ways of measuring diversity usefully map onto different elements of this discussion. Shannon's and Simpson's indexes provide useful ways of comparing diversity amongst the major obsidian sources in use at any one site, or between individual phases at a particular site. 
This means that the presence of a tail of sources that only rarely occur should not dominate the measure of diversity of supply. Equally though, a simple richness index coupled with the Chao 1 estimator may allow us to understand the total range of sources that were exploited, and take account of the occurrence of rare sources.

However, not all diversity indexes will represent the same thing, even when they allow us to compare different sites more directly, because the location of sites in relation to the potential sources varies. A site, such as Domuztepe, that is positioned between the central Anatolian and the eastern Anatolian sources, will have a wider potential set of sources at similar distances to draw on. This variability cannot be easily excluded from influencing the analysis and must be explored in interpretation.

\subsection{The dataset}

The selection of sites used here (Table 1; Fig. 2) is drawn from two broad regions, Mesopotamia and the Levant. The sites in each region obtained their obsidian from a broadly similar direction and, although distances to individual sources obviously vary, both central and south-east Anatolian obsidian is utilised. Sites close to particular source areas such as Çatalhöyük (Carter and Milić, 2013b) or where the relationship is with very different source areas have been excluded here (e.g., Sos Höyük, Kobayashi, 2006), even where sample sizes might be quite large. At this stage in our analysis, the selection of sites is not comprehensive as in this paper our intention is simply to explore approaches and suggest patterns.

Geographically we have made a broad distinction between Mesopotamian and Levantine sites in Figures 2 and 3. This is rather arbitrary and to some extent is structured in this way to give coherence to assemblages unequally distributed in time and space. It is viewed as a heuristic device to help explore the differentiation of two notionally different distribution networks that may have existed. As availability of large samples increases, we would expect more nuanced geographical distinctions to be vital. Sites in the middle Euphrates valley and east of it have been grouped as Mesopotamian. In these figures, Domuztepe is categorised as a Mesopotamian site in Figure 3 but this is essentially arbitrary. It would be equally reasonable to class it as Levantine as it lies in the northern extension of the Great Rift Valley and may provide an important insight to a region through which supply to the southern Levant may have flowed. In the discussion below, it is sometimes also considered as a site at the north of the Levantine corridor rather than being in one or other region. In what follows regional patterns are viewed as flexible, with the strict regional divisions downplayed.

In general, we have not at this stage re-examined primary elemental data so the original analyst's interpretation of source assignation has been accepted. Analyses which do not distinguish Bingöl A 
from Nemrut Dağ have not been used. In instances where these two sources have been distinguished in an assemblage but where there are a few unresolved cases, the latter have been divided between the two sources. Artefacts not assigned to a specific source have been excluded entirely. While these may genuinely represent unknown sources, they can be considered more generically to be compositions that do not easily cluster with known sources. This could be for several reasons, including lack of samples from particular geological sources in the original study as well as issues of possible sample contamination or analytical bias.

In this initial study, small sample sizes have been excluded because of issues in determining their level of bias and the potential impact on diversity indexes. The cut-off used has been rather arbitrary at about 20-30 analysed samples for a site. While smaller samples may still be useful, there are often real problems around how the samples have been selected. Sometimes it is explicit that this has been done to select a diversity of physical types, or to exclude too many peralkaline obsidians as they are known to come from only two sources. We know from our work on the Domuztepe assemblage that, while this can be very effective at revealing a diversity of sources in a small sample, it can also distort this significantly and measures such as the Chao 1 estimate are very sensitive to singletons.

Dating the different assemblages is an enormously complex topic. We have attempted to split major phases of occupation at individual sites as much as possible, so the unit of analysis is generally the phase rather than the site as a whole. However, phases do vary significantly in length and at present cannot be studied on the level of individual occupational events. The dates assigned in creating Figure 3 are single date approximations, based, where available, on absolute dates from the sites and the phases represented. In reality, they all represent ranges and might realistically move slightly on the $x$-axis if they reflected a more nuanced view of the chronology. In the context of the general trends discussed here, this is felt to be sufficient but is open to revision in future, particularly as finer resolution becomes possible amongst obsidian assemblages.

\section{Results and Discussion}

\subsection{Major sources}

Most assemblages have one or more sources that clearly dominate the assemblage (Fig. 4). Very often these major sources make up more than $90 \%$ of the total analysed assemblage and, as a general rule, we have taken $10 \%$ as the boundary at which the contribution of a single source can be considered major for the purposes of this discussion. While this is an arbitrary division, used mainly to give structure to the discussion rather than as a fundamental statement, the identification of the major sources is rarely ambiguous and may be a useful empirical measure. 
The reasons for particular sources dominating at an individual site are probably quite complex. While it may simply be a factor of distance, reflecting travel time and cost, with the closer sources providing most of the obsidian, it is clear that this is not necessarily the case and other considerations may have been relevant. It might reflect a preference for obsidian with desirable physical qualities, perhaps functional but possibly also aspects like colour. Equally a site might have had privileged access to a particular source through specific social networks that made it preferable to a closer alternative, or access may have been embedded in the seasonal movement of nomads.

Interpretative models of obsidian distribution have tended to portray obsidian use as long-term trends (e.g., Renfrew et al., 1968; Renfrew, 1975, 1977; Cauvin and Chataigner, 1998; Khalidi et al., 2016). While that may partially be true, we need to be aware that this has also been an assumption required to allow us to generalise from limited samples. In fact, there is reason to think that obsidian use can fluctuate significantly in quite short time spans. For example, in the overall pattern of obsidian use in north Iraq, the very high quantities of obsidian at Magzaliyah is difficult to reconcile with both preceding and following periods (Healey, 2007).

In the more detailed understanding of the use of different sources of obsidian at individual sites, the contextual understanding of obsidian use requires a much larger sample size. From the perspective of a whole site, this is not immediately apparent. Previous studies of the obsidian from Umm Dabaghiyah in northern Iraq involved the provenance analysis of seven artefacts, all 'informally' collected from the surface of the site (three artefacts in Hall and Shackley, 1994; four artefacts in Khalidi et al., 2016). This determined that four artefacts were of obsidian from Nemrut Dağ, two from Bingöl B and one from Bingöl A. Our new analysis of 675 artefacts adds precision. The three obsidian sources identified in previous studies are confirmed as the dominant sources. However, it also showed that Bingöl B was consistently the main source of obsidian used at the site. Although further work remains to be completed, the dominance of Bingöl B obsidian probably increased through time, with Bingöl A and Nemrut Dağ becoming increasingly less significant. Whether there is any spatial structure in the use of obsidian across the site remains to be confirmed. We do know, however, that there was no techno-morphological difference in the use of the obsidian from the main sources.

At Kenan Tepe, obsidian from a limited set of sources dominate the assemblage throughout the occupation of the site. However, broken down into sub-phases during the Ubaid occupation, the use of sources fluctuated very considerably over a relatively short time period (Fig. 5; Campbell and Healey, 2016). This does not appear to reflect a systematic long-term diachronic change but differentiation between different sub-communities that have been sampled within the Ubaid period, 
perhaps reacting to short-term factors, including season, but also reflecting their different social networks.

When the use of different sources has been broadly sketched out as a long-term phenomenon, there is a general tendency to see additional sources being used over time. This can be approached more formally by looking at trends in the diversity of sources used in different areas through time (Table 1; Fig. 3). As discussed above, Shannon's and Simpson's diversity indexes are particularly appropriate to look at the major sources that were exploited, as they accentuate the evenness of use of the most common classes. In fact, Shannon's and Simpson's diversity indexes reassuringly show an almost identical pattern. While many of the elements of this pattern have been previously noted, it is useful to have a systematic and extensible overview, with additional data drawn from sites not included in the formal diversity analysis.

In the Later Upper and Epi-palaeolithic the evidence is very sporadic and obsidian use low, but already we see different sources being used. In northern Mesopotamia, obsidian was found at Shanidar Cave likely from context C (Upper Palaeolithic), although we cannot rule out the possibility of contamination due to the nature of the excavation. Two flakes were provenanced by Renfrew to different sources (Renfrew et al., 1966, number 303 to his group 4c, the other, 304, to his group 1ef; Chataigner, 1998: 293-294 suggested that the most likely attributions were Nemrut Dağ and Süphan Dağ respectively). Reanalysis by MOL allows us to attribute them to Bingöl $A$ and to Sarıkamış 1. In the Levant on the other hand, a scraper of Epipalaeolithic date from Yabroud II came from Göllüdağ East (Frahm and Hauck, 2017) but, a little later and equally far from source, a corerejuvenation flake from the Öküzini cave in south western Anatolia is provenanced to Nenezi Dağ (Carter et al., 2011). Even earlier, Göllüdağ East obsidian is present in the Aurignacian and later levels at the Öküzini and Karaın B caves (Carter et al., 2011: 135; Renfrew et al., 1966: 42).

In the Natufian, PPNA and PPNB periods, the Levant shows a very heavy concentration on only a few sources and, in particular, a focus on Göllüdağ East. Tell Labwe South in the PPNB phase is the main exception, with a relatively high diversity index; Shannon's index is 0.80 for the PPNB phase of this site. This might be because of its location in the northern Levant but perhaps because it may be rather late PPNB in date and belong to a changing pattern of obsidian distribution. The pattern in northern Mesopotamia at this time is rather more varied, even in the Aceramic Neolithic, with most sites exploiting more than one source to a significant level. This does not simply reflect the different distances to sources. While the Mesopotamian sites do have somewhat more equidistant access to a wider range of sources (Fig. 2), the distance from Bingöl to the southern Levantine sites, for example, is not sufficiently greater than the distance from Göllüdağ to account for such dominance of the latter source. And in both cases access in its initial stages is through similarly mountainous 
terrain. Instead, the network distributing Göllüdağ East obsidian seems to penetrate much more efficiently into the Levant, perhaps due to the use of sea routes but very probably because of social links.

In northern Mesopotamia in the Aceramic Neolithic, obsidian from Bingöl B was preferred to that from Nemrut Dağ at Körtik Tepe (PPNA), Dja'de and Qdeir 1 (PPNB, Middle Euphrates), with Bingöl A obsidian often also present in lesser quantities. This dominance of Bingöl B, seems to have persisted into the Ceramic Neolithic at sites such as Umm Dabaghiyah and Abu Hureyra. It was possibly also the case at Tell Shimshara where Renfrew recorded 80\% grey obsidian (Renfrew, 1970: Table 141).

The Levantine sites draw on a significantly more diverse range of sources for the majority of their obsidian after ca. $7000 \mathrm{cal} \mathrm{BC}$, during the later Neolithic. That is most obviously the case at the very north of the Levantine corridor, at Domuztepe where Göllüdağ East, Bingöl A and Bingöl B are all major suppliers of obsidian in levels post-dating $6000 \mathrm{cal} \mathrm{BC}$, resulting in a Shannon's index of 1.85; as discussed below obsidian was also obtained from a remarkably wide range of other sources. This is not simply because Domuztepe is geographically between sources. Hagoshrim, Tell Arqa and the Pottery Neolithic levels at Tell Labwe South, all located further south, have obsidian from a similar diversity of sources, with Shannon's indices of 1.76, 1.19 and 0.88 respectively. If we postulate that access routes to the southern Levant came together in the northern Great Rift Valley, it may make a great deal of sense that the pattern of diversity at Domuztepe is mirrored further south.

This diversity becomes more marked between ca. 7000 and 4500 cal BC in Mesopotamia too. Sites tend to utilise several major sources with a relative balance between them. Not surprisingly Bingöl A, Bingöl B and Nemrut Dağ are common suppliers but Meydan Dağ sees significant use at Arpachiyah. For the first time Group 3d, an obsidian source as yet not definitively located (Chataigner, 1998; Campbell and Healey, in prep.; Khalidi et al., 2016: 747), sees large scale use at Kenan Tepe. It is clear from the breakdown of obsidian use during individual phases at Kenan Tepe that the precise balance of obsidian source use varies but the diversity profile of relatively even use of varied sources remains characteristic. At this stage, it is not only the case that diversity of the obsidian sources used increases, but it is driven by an increasing use of peralkaline obsidian sources in northern Iraq and north-east Syria, with obsidian from Nemrut Dağ at least starting to be utilised in large quantities.

When discussing long-term trends, later prehistoric and historic periods have tended to be neglected. Obsidian remains widely exploited in the Late Chalcolithic and Early Bronze Age, although there is also a shift to more extensive use for decorative items in both Mesopotamia and the Levant. There are indications that the large scale use of sources changes significantly, although patterns are not yet completely clear. In the Assyrian Trade Colony period, for example, stores of obsidian in the 
palace workshops at Kültepe-Kaneš (Özgüç, 1996) and the Level VII palace at Alalakh (Woolley, 1955) suggest that it had become commodified. At Tell Mozan in northern Syria obsidian from a diverse range of sources including Göllüdağ East has been recorded (Frahm and Feinberg, 2013a), reflected in a Shannon's index of 1.21. This diversity is particularly marked in the obsidian used to make the beads found together in an Early Dynastic (ca. 2700 cal BC) tomb at Kish, in southern Iraq. The obsidian used for the manufacture of 105 beads comes from four different source groups in varying proportion (Campbell and Healey, forthcoming). Unexpectedly none are from the main source groups previously exploited, but include significant use of Tendürek Dağ (Diyadin) and two Syunik sources in Armenia as well as Meydan Dağ. This picture is not unusual. The analysis of individual beads and other artefacts from southern Mesopotamia from a similar time period demonstrates a wide range of sources being used and the significance of Armenian sources in southern Mesopotamia at this time is gradually emerging. So too in the Levant in the Early Bronze Age both Group 3d and Bingöl A obsidian are attested alongside Göllüdağ obsidian at Jericho, although the sample is small. Here we might note the obsidian vessels with some Egyptian characteristics especially those from Tell 'Ajjul and Tell Atchana. Neither they nor any workshop debris has been provenanced, so it is not possible to determine whether they are imitations of Egyptian artefacts made of Anatolian obsidian or whether they are of Arabian or East African obsidian and likely acquired as finished objects along with other examples (cf., Sparks, 2007: 121; see also Healey forthcoming). To date the only piece of obsidian of likely Egyptian origin provenanced is a small flake from a bowl from Hुattuša (Böğazköy) with a cartouche of the Hyksos pharaoh Chian engraved on it, which Zarins determined to be of Red Sea obsidian (Zarins, 1989: 367-368). Renfrew also provenanced an unstratified chip from Hattuša which he attributed to his Ethiopian group $4 d$, (Renfrew et al., 1966: no. 295).

\subsection{Minority sources}

While obsidian from a small number of sources tends to dominate assemblages across the Levant and Mesopotamia, in almost every assemblage there are also artefacts from sources which do not contribute in any major way to the supply of obsidian in the region under discussion. While these sources were probably never economically significant, they may be informative in a number of ways (Tykot, 2011; Milić, 2016). Sometimes it is simply a matter of a few artefacts from well-known sources which are only rarely used outside their immediate locality, such as some of the Armenian obsidians (Frahm et al., 2016). On other occasions, however, the artefact(s) may be from a source which has not been well studied such as those in north-east Anatolia, including Sarıkamış, Kars and Pasinler (Chataigner et al., 2014), and eastern Anatolia, including Muş and Tendürek Dağ. The use of obsidian from these lesser known sources, as we have seen in the case of the beads from Kish, 
emphasizes that a comprehensive geo-referenced source dataset is essential for recognition of these sources and the correct assignment of artefacts to source (cf., Frahm, 2012b).

There are a number of possible approaches we can adopt to interpreting the use of these sources. One is to consider each source, or group of sources when they occur in a similar geographic region, on their own merits as the potential centre of a regional network of exchange and interaction. If obsidian distribution was driven through exchange between settlements, rather than simply directional acquisition from source, distribution networks might be dominated by the more accessible major sources within an individual region but this need not be to the exclusion of other obsidian. The edges of the regional networks may be porous. The presence of obsidian from these minority, sometimes 'exotic', sources may represent the slipping of some obsidian from one distribution network in which it is in a majority, into another one in which it is very rare. In this case, the occasional artefact of these obsidians in a site assemblage might provide indications that lateral exchange between settlements was taking place (as, for example, in the case of the Armenian obsidians at Domuztepe). It has been recently emphasised that simple down-the-line models cannot account for the distribution of obsidian over long distances, requiring instead at least some nodes that create links over longer distances (Ibáñez et al., 2015; Ortega et al., 2016). This places particular interest on settlements which may have been able to develop and maintain distant exchange links that bridge different regional exchange networks.

However, we should also remember that obsidian distributions may reflect, no matter how indirectly, some knowledge of its origin and the network through which it was obtained. This has already been noted as a possibility in the cases of the Rouj Basin and Akarçay Tepe (Maeda, 2003, 2013) and Körtik Tepe (Carter et al., 2013). We might even consider that physical characteristics that may distinguish some of these minority sources may have influenced the role that obsidian played. At Domuztepe, for example, there is a high correlation between brown or mahogany obsidian and sources in north-east Anatolia, particularly Pasinler, and in Armenia, particularly Pokr Arteni (Healey and Campbell, 2009; Frahm et al., 2016). Although brown and mahogany coloured obsidian also occurs at other sources that were utilised at Domuztepe, such as Meydan Dağ and Göllüdağ East, they are extremely rare in the provenanced artefact assemblage, so this choice might indicate a motivation rooted in socially ascribed value. The colours may have been selected on a subtle but specific level that is more refined than our rather generalised modern perspective. Possibly the selection was not simply about physical characteristics but that physical appearance materialised specific social networks and much longer distance connections. Something not dissimilar has been noted for obsidian at Göbekli Tepe in south-east Turkey. Tristan Carter has suggested that the 
diversity of obsidian sources evidenced at the site is directly linked to that site's supra-regional connections (cited in Notroff et al., 2015: 73; see also Carter et al., 2013: 567).

A system of obsidian acquisition need not simply be about minimising the cost of acquisition of a necessary material and may well be guided by diverse motivations. It represents a complex product of the values placed on material by society and may involve multiple modes of acquisition and systems of value. The major obsidian source exploitation might be driven by one set of motivations, while the acquisition of minority types of obsidian may be driven by a very different set of considerations.

While tracking the wider use of specific sources can be helpful, the range of obsidian use at individual sites, and potentially contexts within a site, is something that is valuable to look at as a characteristic in itself. For the use of minority sources of obsidian at individual sites, we are mainly concerned with measures of richness (i.e. the number of obsidian sources used at that site), both the richness index itself and the Chao 1 estimate of the underlying pattern (Fig. 3). As with Shannon's and Simpson's indexes, the patterns that these produce are largely similar. Although the use of Chao 1 estimates emphasises some patterns, they are generally already visible in the simple richness index.

In general, richness increases significantly over time but this is not a simple unilinear trend. While the earliest sites included in our diversity graphs are the Natufian assemblage from Mallaha and the Proto-Neolithic from Jericho, entirely comprised of Göllüdağ East obsidian, it has been noted above that, prior to this, Nenezi Dağ obsidian was used at the Öküzini cave (Carter et al., 2011) and obsidian from two different sources was present at Shanidar (Renfrew et al., 1966; Chataigner, 1998). There is increasing richness throughout the Aceramic Neolithic even in the Levant, with eastern Anatolian obsidian appearing in very low quantities.

From ca. 7000 to ca. 5000 cal BC, during the Ceramic Neolithic, there is a peak in the richness of obsidian sources both in Mesopotamia and in the Levant. In terms of exceptionally high simple richness indexes of 11 and 9 for Domuztepe and Kenan Tepe stand out. While it is certainly true that the range of obsidian sources used at Domuztepe is unusually diverse, this may also be distorted by an initial sampling strategy that has selected visually distinct obsidian for characterisation. It is worth noting, however, that the Chao 1 estimate of 13 suggests Kenan Tepe might be even more diverse if the sample had been increased yet further. Given the sample size at Kenan Tepe is 882 , this may be an argument that sampling to redundancy would be very challenging but it perhaps also suggests that the north-central location of the site may have allowed material from north-east Anatolia and Armenia to penetrate the routeways between Bingöl and Nemrut Dağ. The high Chao 1 estimate of 10 for Tell Arqa suggests that this pattern of very high diversity in the late $7^{\text {th }}$ and $6^{\text {th }}$ millennia cal BC 
may be characteristic of sites further south in the Levant as well, with Hagoshrim and Tell Labwe South also showing significant diversity at this time.

There appears to be a decline in richness after the late $5^{\text {th }}$ millennium cal $B C$, particularly visible in the Chao 1 estimates of sample richness. While we suspect that this may reflect a genuine trend, it may also be associated with sampling. Samples sizes in this period are smaller and the Chao 1 estimate works using singleton and doubleton appearances of obsidian sources. If the sample size is too small, even singletons may not appear. The later samples are also rather scattered and the pattern may be influenced by geographical bias. However, this decline in richness occurs in a period in Mesopotamia, when new major obsidian sources seem to be exploited. The whole dynamic of obsidian distribution networks may have been changing in the context of increasingly complex societies, which probably integrated increasingly large areas.

The increasing diversity in richness broadly corresponds with the trend identified above for an increased range of major sources to be used over time, with a more even spread between sources. At the same time the increased richness of minority source use, may suggest changes in the value ascribed to obsidian from more exotic locations. Changes in long distance contacts, perhaps linked to new routes and new forms of mobility, may have promoted long distance links between some communities that resulted in more 'leakage' of neighbouring obsidian exchange networks into those of Mesopotamia and the Levant.

When rare obsidian occurs, it comes from a wide range of sources. Eventually we must seek explanations specific to individual sites and individual obsidian sources, but different categories of rare sources may be noted. Some are similar distances to more common sources but might be harder to access or depend on the development of different routeways. For sites that already made use of eastern Anatolian sources, the use of Meydan Dağ and Tendürek Dağ (Diyadin) obsidian may fall into this category. Sometimes, this increased diversity is specifically associated with exploitation of obsidian of lower quality. Both Group 3d and Muş obsidian probably falls into that grouping as ease of access was probably very similar to the more common Bingöl and Nemrut Dağ obsidians. These shifts might reflect procurement embedded in other activities (e.g., herding or trading for other commodities along new routeways), curiosity about exploring and exploiting the landscape or perhaps an occasional need to exploit alternative resources when preferred resources could not be accessed.

Over time, there appears to be a growing tendency to acquire obsidian from minority sources that are much further distant, where we might expect any supply to be overwhelmed by closer sources, particularly the north-east Anatolian and Armenian sources (Frahm et al., 2016). Not only are the sources much more distant from Mesopotamia and the Levant but the shortest routeways to 
these areas run very close to the major sources at Bingöl and Nemrut Dağ (Fig. 2). In the early 6th millennium cal BC, their use is particularly characteristic of a Levantine corridor with Domuztepe at the north (Frahm et al., 2016). This might suggest that indirect routeways were appearing that might by-pass the major eastern Anatolian sources.

Many of these minority sources almost only ever appear as rare obsidian at sites in Mesopotamia and the Levant. However, occasionally they can occur as a significant source. Thus, at Kenan Tepe, Group 3d obsidian is consistently a major component of the obsidian assemblage and, in the Ubaid Phase 4, it is the dominant type used (Campbell and Healey, 2016). It may be a short-term temporal change, perhaps driven by factors restricting access to preferred obsidian supplies. At Arpachiyah in northern Iraq, Nemrut Dağ, Bingöl A and B all provide significant quantities of obsidian. However, both the previous analysis of obsidian from the site (Renfrew et al., 1966; Renfrew et al., 1968; Forster and Grave, 2012; Khalidi et al., 2016) and the larger sample that we have studied more recently suggest that Meydan Dağ was also a major supplier. By the $3^{\text {rd }}$ and $2^{\text {nd }}$ millennia cal $B C$ in Mesopotamia, Armenian sources such as Syunik, previously very rare, also seem to become significant suppliers.

\section{Conclusions}

The presence of obsidian artefacts in communities distant from its sources has become a proxy for exchange. However, this has tended to isolate obsidian as only being about isolated resource procurement. Its acquisition would rarely have been in isolation but in parallel with other activities, such as seasonal mobility and social obligations. It was also certainly not the only commodity moving across long distances, with shells being particularly well attested in prehistoric periods in the Middle East (Bar-Yosef Mayer, 2005, 2008; Delage, 2017). We also need to avoid a focus on a purely functional view of exchange. Exchange is bound up with social relationships and socially imposed meanings of material.

As it has become more common to provenance large numbers of artefacts from a single assemblage or even complete or near complete assemblages, new interpretative possibilities develop that accord more closely with the focus of contemporary archaeology (cf., Tykot, 2011). Thus, we have seen that communities may acquire obsidian in different forms from different sources, for example at Körtik Tepe (Carter et al., 2014) and Tell Hamoukar the reduction of raw nodules implies direct access to the source, whereas at nearby Tell Brak this is not the case (Khalidi et al., 2009). Other communities may choose a particular obsidian for a certain task. There are striking examples from the late Neolithic settlement in the Rouj basin and at Akarçay Tepe where people made deliberate choices in what they used obsidian from different sources for (Maeda, 2009: 144, 150, 153, 2013: 269ff.). 
Provenance analysis of large assemblages of obsidian allows a new focus on the use of unusual and rare sources. We certainly agree with the recent suggestion that obsidian exchange systems in general provide key insights into the importance of networks of interaction in the success of the Neolithic in the Middle East (Ibáñez et al., 2015). The regular but rare presence of obsidian from exotic sources, particularly from the late Neolithic onwards, suggests that the ability to create bridges across regional networks may have remained equally important in creating and maintaining social ties over long distances.

The study of large assemblages focusses attention on both on the techno-typological make-up of the assemblages and on the sources themselves. To develop our understanding and interpretation of the acquisition and use of obsidian, it will be important to integrate the techno-typological composition of assemblages with provenance analysis in order that models of network analysis can use a full range of data to maximize our understanding. Equally, detailed work on the sources as at Göllüdağ (Binder et al., 2011) and Nemrut Dağ (Robin et al., 2016) and elsewhere needs to be continued and developed alongside comprehensive documentation of the archaeological use of the obsidian from these sources. However, most sources remain less well known, and this particularly impacts our understanding of the more rarely used sources. These are not only poorly known in geological and compositional terms but their local exploitation is often poorly documented because archaeological surveys and excavation of sites close to the sources has often been less intense. This makes it hard to understand how different networks of obsidian distribution overlapped and interacted.

Large assemblages also require the development of different tools to summarise, integrate and compare greater quantities of data. Here, we have explored the use of diversity indexes to help understand the variety of obsidian exploitation and how it changes. The assemblages considered remain relatively few in number. Much of our analysis has retained the site as the main unit of analysis, not only because our work is still developing but because the contextual information that is required for more subtle analysis has not always been available.

The results of our analyses do not alter the perception that the bulk of obsidian in the Middle East was obtained from four predominant sources: Nemrut Dağ, Bingöl A and Bingöl B in the east and Göllüdağ East in central Anatolia. However, they do show a much more fluid and nuanced picture of the extent to which these sources were used. In many ways, research is still at a preliminary stage, full of potential but needing a rapid expansion of data and interpretation. As well as the need to analyse more artefacts from assemblages we should also integrate their technotypological characteristics into the broader narrative of social meaning. So too, the investigation of the relationship between sites and sources over time needs to be sensitive to short-term change and 
contextual specificity. As important is the increasing recognition of obsidian from minority sources. In previous studies these have been under appreciated but they may provide information on how past networks of distribution interacted and the complexity of values attached to the use of obsidian in the past.

\section{Acknowledgements}

We are grateful to many individuals who have contributed to elements of this paper. Peder Mortensen and Susanne Kerner provided access to the Umm Dabaghiyah obsidian in the University of Copenhagen. Paul Collins and Imogen Gunn helped enormously with access to material in the Ashmolean Museum and the Museum of Archaeology and Anthropology, Cambridge respectively. Bradley Parker, University of Utah, provided access to the obsidian from Kenan Tepe. Different portions of the obsidian from Domuztepe have been analysed by J.-L. Poidevin, Ellery Frahm and Joseph Lehner as well as MOL; we are pleased to acknowledge their contributions. For access to and information about source material, we are grateful to Akihiko Mochizuchi and Katsuji Kobayashi as well as Francois-Xavier Le Bourdonnec, Kristine Martirosyan-Olshansky, Osamu Maeda, Ellery Frahm and Mike Glascock. Osamu Maeda has been closely involved in the primary analysis of obsidian referenced in the paper, and we are indebted to his support. Some of the background support for the early stages of the project came from a British Academy Small Research Grant. This paper has benefitted greatly from the feedback of four anonymous reviewers and the editorial input of Yaroslav Kuzmin. Remaining errors, of course, remain our responsibility.

\section{Figures}

1. Map with the major obsidian sources for the Middle East. Key sources labelled

2. Map with archaeological sites mentioned in the text (Triangles = Levantine sites with diversity indexes in Table 1; Circles = Mesopotamia sites with diversity indexes in Table 1; Squares $=$ other sites mentioned in the text).

3. Graphs showing diversity indexes for selected sites.

4. Graph showing the proportions of obsidian sources that supply at least $10 \%$ of the obsidian assemblage. Selected sites, where 20-30 obsidian samples have been sourced.

5. Obsidian use at Kenan Tepe in the four Ubaid phases.

\section{Tables}

1. Table of diversity indexes.

\section{References}


Abbès, F., Bellot-Gurlet, L., Bressy, C., Cauvin, M.-C., Gratuze, B., Poupeau, G., 2001. Nouvelles recherches sur l'obsidienne de Cheikh Hassan (vallée de l'Euphrate, Syrie) au Néolithique: PPNA et PPNB ancien. Syria 78, 5-17.

Abbès, F., Bellot-Gurlet, L., Cauvin, M.C., Delerue, S., Dubernet, S., Poupeau, G., Stordeur, D., 2003. Provenance of the Jerf el Ahmar (Middle Euphrates Valley, Syria) obsidians. J. Non-Cryst. Solids 323, 162-166.

Akköprü, E., Mouralis, D., Robin, A.-K., Kuzucuoğlu, C., Erturaç, M.K., 2017. Doğu Anadolu'daki obsidiyen kaynak qlanlarının belirlenmesinde jeomorfolojik ve volkanolojik göstergelerin önemi. The Importance of the geomorphological and volcanological indicators in determining obsidian source areas. Geol. Bull. Turkey 60, 47-61.

Astruc, L, Gratuze, B., Pelegrin, J., Akkermans, P., 2007. From production to use: a parcel of obsidian bladelets at Sabi Abyad II. In: Astruc, L., Binder, D., Briois, F. (Eds.), Technical Systems and Near Eastern PPN Communities. Editions APDCA, Antibes, pp. 327-341.

Balkan-Atlı, N., Kayacan, N., Balci, S., Astruc, L., Erturaç, K., 2013. Göllü Dağ Obsidian Project. In: Borrell, F., Ibañez J.J., Molist M. (Eds.), Stone Tools in Transition: From Hunter-Gatherers to Farming Societies in the Near East. Bellaterra, Barcelona: Universitat Autònoma de Barcelona, pp. 465-474.

Baxter, M.J., 2003. Statistics in Archaeology. Arnold, London.

Bar-Yosef Mayer, D.E., 2005. The exploitation of shells as beads in the Palaeolithic and Neolithic of the Levant. Paléorient 31(1), 176-185.

Bar-Yosef Mayer, D.E., 2008. Dentalium shells used by hunter-gatherers and pastoralists in the Levant. Archaeofauna 17, 103-110.

Bellot Gurlet, L., 1998. Caractérisation par analyse élémentaire (PIXE et ICP-MS/-AES) d'un verre naturel: I'obsidienne. Application à l'étude de provenance d'objets archéologique. Unpublished Ph.D. thesis, University Joseph Fourier-Grenoble 1.

Biagi, P., Gratuze, B., 2016. New data on source characterization and exploitation of obsidian from the Chikiani area (Georgia). Eurasiatica 6, Armenia, Caucaso e Asia Centrale, 9-35.

Binder, D., Gratuze, B., Mouralis, D., Balkan-Atlı, N., 2011. New investigations of the Göllüdağ obsidian lava flows system: a multi-disciplinary approach. J. Archaeol. Sci. 38, 3174-3184.

Blackman, M.J., Hole, F., Rosenberg, M., Magness-Gardner, B., Rollefson, G., 1993. The Greater Mesopotamian Obsidian Exchange Project. Conservation Analytical Reports for 1993. Smithsonian Institution, Washington. Available at: https://www.si.edu/mci/downloads/AnnualReports/Research_Report_1993.pdf.

Briois, F., Gratuze, B., Guilllaine, J.E., 1997. Obsidiennes du site néolithique précéramique de Shillourokambos (Chypre). Paléorient 23(1), 95-112.

Brumm, A. 2010. 'The Falling Sky': symbolic and cosmological associations of the Mt William Greenstone axe quarry, Central Victoria, Australia. Camb. Archaeol. J. 20(2), 179-196.

Campbell, S., Healey, E., 2016. Multiple sources: The pXRF analysis of obsidian from Kenan Tepe, S.E. Turkey. J. Archaeol. Sci. Reports 10, 377-389.

Campbell, S., Healey, E., forthcoming. The sources of some obsidian beads found at Kish, Southern Iraq. In: Pereira, T., Terradas Batlle, X., Bicho, N. (Eds.), The Exploitation of Raw Materials in Prehistory: Sourcing, Processing and Distribution. Chapter 37. Cambridge Scholars Press, Cambridge.

Carter, T., 2014. The contribution of obsidian characterization studies to early prehistoric archaeology. In: Yamada, M., Ono, A. (Eds.), Lithic Raw Material Exploitation and Circulation in Prehistory. A Comparative Perspective in Diverse Palaeoenvironments. ERAUL, University of Liège, pp. 23-33.

Carter, T., Aubert, D., Brown, K., Doyle, S., 2012. Networking in the Neolithic: obsidian sourcing at Abu Hureyra (N. Syria). Presented at the Annual Meeting of the American Schools of Oriental Research, Chicago (USA), November 2012. Available at: https://maxlab.mcmaster.ca/documents/asor-abu-hureyra-poster-final.pdf. 
Carter, T., Bourdonnec, F.-X. le, Kartal, M., Poupeau, G., Calligaro, T., Moretto, P., 2011. Marginal perspectives: sourcing Epi-Palaeolithic to Chalcolithic obsidian from the Öküzini Cave (SW Turkey). Paléorient 37(2), 123-149.

Carter, T., Grant, S., Kartal, M., Coşkun, A., Özkaya, V., 2013. Networks and Neolithisation: sourcing obsidian from Körtik Tepe (SE Anatolia). J. Archaeol. Sci. 40, 556-569.

Carter, T., Milić, M., 2013a. Chipped stone. In: Hodder, I. (Ed.), Substantive Technologies at Çatalhöyük: Reports from the 2000-2008 Seasons. Çatalhöyük Research Project Vol. 9. Cotsen Institute of Archaeology Press, Los Angeles, pp. 417-478.

Carter, T., Milić, M., 2013b. The consumption of obsidian at Neolithic Çatalhöyük: a long-term perspective. In: Borrell, F., Ibáñez, J.J., Molist, M. (Eds.), Stone Tools in Transition: From Hunter-Gatherers to Farming Societies in the Near East. Bellaterra, Barcelona: Universitat Autònoma de Barcelona, pp. 495-508.

Carter, T., Batist, Z., Campeau, K., Garfinkel, Y., Streit, K., 2017. Investigating Pottery Neolithic socioeconomic "regression" in the Southern Levant: Characterising obsidian consumption at Sha'ar Hagolan (N. Israel). J. Archaeol. Sci. Reports 15, 305-317.

Cauvin, M.-C., Chataigner, C., 1998, Distribution de l'obsidienne dans les sites archéologiques du proche et moyen orient (par phase chronologique). In: Cauvin, M.-C., Gourgaud, A., Gratuze, B., Arnaud, N., Poupeau, G., Poidevin, J.-L., Chataigner, C. (Eds.), L'Obsidienne au Proche et Moyen Orient: Du Volcan à l'Outil. Archaeopress, Oxford, pp. 325-350.

Cauvin, M.C., Besnus, Y., Tripier, J., Montigny, R., 1991. Nouvelles analyses d'obsidiennes du Proche Orient: modèle de géochemie des magmas utilisé pour la recherche archéologique. Paléorient 17(2), 5-20.

Cauvin, M.-C., Gourgaud, A., Gratuze, B., Arnaud, N., Poupeau, G., Poidevin, J.-L., Chataigner, C., 1998. L'Obsidienne au Proche et Moyen Orient: Du Volcan à l'Outil. Archaeopress, Oxford.

Chao, A., 1984. Nonparametric estimation of the number of classes in a population. Scand. J. Stat. 11. 265-270.

Chao, A., Gotelli, N.J., Hsieh, T.C., Sander, E.L., Ma, K.H., Colwell, R.K., Ellison, A.M., 2014. Rarefaction and extrapolation with Hill numbers: a framework for sampling and estimation in species diversity studies. Ecological Monographs 84, 45-67.

Chataigner, C., 1994. Les propriétés géochimiques des obsidiennes et la distinction des sources de Bingöl et du Nemrut Dağ. Paléorient 20(2), 9-17.

Chataigner, C., 1998. Sources des artefacts du Proche Orient d'après leur caractérisation géochimique. In: Cauvin, M.-C.,Gourgaud, A., Gratuze, B., Arnaud, N.,Poupeau, G., Poidevin, J.L., Chataigner, C. (Eds.), L'Obsidienne au Proche et Moyen Orient. Du Volcan à l'Outil. Archaeopress, Oxford, pp. 273-324.

Chataigner, C., Barge. O., 2008. Quantitative approach to the diffusion of obsidian in the ancient northern Near East. In: Posluschny, A., Lambers, K., Herzog, I. (Eds.), Layers of Perception. Proceedings of the 35th International Conference on Computer Applications and Quantitative Methods in Archaeology (CAA), Berlin, April 2-6, 2007. Dr. Rudolf Habelt GmbH, Bonn, pp. 17.

Chataigner, C., Gratuze, B., 2014a. New data on the exploitation of obsidian in the southern Caucasus (Armenia, Georgia) and eastern Turkey, Part 1: source characterization. Archaeometry 56, 25-47.

Chataigner, C., Gratuze, B., 2014b. New data on the exploitation of obsidian in the southern Caucasus (Armenia, Georgia) and eastern Turkey, Part 2: obsidian procurement from the Upper Palaeolithic to the Late Bronze Age. Archaeometry 56, 48-69.

Chataigner, C., Işikli, M., Gratuze, B., Çil, V., 2014. Obsidian sources in the regions of Erzurum and Kars (North-East Turkey): new data. Archaeometry 56, 351-374.

Cooney, G., 1998. Breaking stones, making places: the social landscape of axe production sites. In: Gibson, A., Simpson D. (Eds.), Prehistoric Ritual and Religion. Sutton Publishing, Phoenix Mill, pp. 108-118. 
Cummins V., Johnston, R. (Eds.), 2007. Prehistoric Journeys. Oxbow Books, Oxford.

Delage, C., 2017. Revisiting rolling stones: the procurement of non-local goods in the Epipaleolithic of the Near East. Quatern. Int. doi:10.1016/j.quaint.2017.07.023

Crawford, H., 1978. The mechanics of the obsidian trade: a suggestion. Antiquity 52, 129-132.

Delerue, S., 2007. L'obsidienne dans le processus de néolithisation du Proche-Orient (12000-6500 BC). Unpublished Ph.D. thesis, Université Michel de Montaigne, Bordeaux 3.

Eerkens, J.W., Spurling, A.M., 2008. Obsidian acquisition and exchange networks: a diachronic perspective on households in the Owens Valley. J. Calif. Gt Basin Anthropol. 28, 111-126.

Epstein, S.M., 1977. The Trade in Near Eastern Obsidians. Unpublished M.A. dissertation, University of Bradford.

Eren, M.I., Chao, A., Chiu, C.-H., Colwell, R.K., Buchanan, B., Boulanger, M., Darwent, J., O'Brien, M.J., 2016. Statistical analysis of paradigmatic class richness supports greater Paleoindian projectile-point diversity in the Southeast. Am. Antiq. 81, 174-192.

Forster, N., Grave, P., 2012. Non-destructive PXRF analysis of museum-curated obsidian from the Near East. J. Archaeol. Sci. 39, 728-736.

Frahm, E., 2010. The Bronze-Age Obsidian Industry at Tell Mozan (Ancient Urkesh), Syria: Redeveloping Electron Microprobe Analysis for 21st-Century Sourcing Research and the Implications for Obsidian Use and Exchange in Northern Mesopotamia after the Neolithic. Unpublished Ph.D. dissertation, University of Minnesota.

Frahm, E., 2012a. Distinguishing Nemrut Dağ and Bingöl A obsidians: geochemical and landscape differences and the archaeological implications. J. Archaeol. Sci. 39, 1436-1444.

Frahm, E., 2012b., What constitutes an obsidian "source"? Bull. Int. Ass. Obsidian St. 46, 16-28.

Frahm, E., 2012c. Fifty years of obsidian sourcing in the Near East: Considering the archaeological zeitgeist and legacies of Renfrew, Dixon, and Cann. Bull. Int. Ass. Obsidian St. 47, 7-16.

Frahm, E., 2013. Validity of "off-the-shelf" handheld portable XRF for sourcing Near Eastern obsidian chip debris. J. Archaeol. Sci. 40, 1080-1092.

Frahm, E., Campbell, S., Healey, E., 2016. Caucasus connections? New data and interpretations for Armenian obsidian in Northern Mesopotamia. J. Archaeol. Sci. Reports 9, 543-564.

Frahm, E., Feinberg, J.M., 2013a. Empires and resources: central Anatolian obsidian at Urkesh (Tell Mozan, Syria) during the Akkadian period. J. Archaeol. Sci. 40, 1122-1135.

Frahm, E., Feinberg, J.M., 2013b. Environment and collapse: eastern Anatolian obsidians at Urkesh (Tell Mozan, Suria) and the third-millennium Mesopotamian urban crisis. J. Archaeol. Sci. 40, 1866-1878.

Frahm, E., Schmidt, B.A., Gasparyan, B., Yeritsyan, B., Karapetian, S., Meliksetian, K., Adler, D.S., 2014. Ten seconds in the field: rapid Armenian obsidian sourcing with portable XRF to inform excavations and surveys. J. Archaeol. Sci. 41, 333-348.

Frahm, E., Hauck. T. C., 2017. Origin of an obsidian scraper at Yabroud Rockshelter II (Syria): Implications for Near Eastern social networks in the Early Upper Palaeolithic. J. Archaeol. Sci. Reports 13, 415-427.

Gratuze, B., 1987. L'obsidienne, matériau témoin des paléoechanges: formation, caractérisation et exploitation. In: Miskovsky, J.-C. (Ed.), Géologie de la Préhistoire : Méthodes, Techniques, Applications. Presses Universitaires de Perpignan, Paris, pp. 961-977.

Hall, M.E., Shackley, S., 1994. An energy dispersive x-ray fluorescence study of some Near Eastern obsidians. Al-Rafidan 15, 25-32.

Healey, E., 2000. The role of obsidian in the late Halaf. Unpublished Ph.D. thesis, University of Manchester.

Healey, E., 2007. Why is there so much obsidian at Tell Magzaliyah? In: Astruc, L., Binder, D., Briois, F. (Eds.), Systèmes Techniques et Communautés Du Néolithique Précéramique Au ProcheOrient. Éditions APDCA, Antibes, pp. 255-265.

Healey, E., forthcoming. The ostentatious use of obsidian in Bronze Age Mesopotamia, Anatolia and the Northern Levant. In: Yener, K.A, Ingman, T. (Eds.), Alalakh and its Neighbors: Proceedings 
of the 15th Anniversary Symposium at the New Hatay Archaeology Museum, June 10-12, 2015. Leuven: Peeters Press, Ancient Near Eastern Studies Series.

Healey, E., Campbell, S., 2009. The challenge of characterising large assemblages of exotic materials: a case study of the obsidian from Domuztepe, SE Turkey. Internet Archaeology 26. doi:10.11141/ia.26.20

Ibáñez, J.J., Ortega, D., Campos, D., Khalidi, L., Méndez, V., Teira, L., 2016. Developing a complex network model of obsidian exchange in the Neolithic Near East: Linear regressions, ethnographic models and archaeological data. Paléorient 42(2), 9-32.

Ibáñez, J.J., Ortega, D., Campos, D., Khalidi, L., Méndez, V., 2015. Testing complex networks of interaction at the onset of the Near Eastern Neolithic using modelling of obsidian exchange. J. Roy. Soc. Interface 12. doi:10.1098/rsif.2015.0210

Kandler, A., Laland, K.N., 2009. An investigation of the relationship between innovation and cultural diversity. Theor. Popul. Biol. 76, 59-67.

Khalidi, L., Gratuze, B., Boucetta, S., 2009. Provenance of obsidian excavated from Late Chalcolithic levels at the sites of Tell Hamoukar and Tell Brak, Syria. Archaeometry 51, 879-893.

Khalidi, L., Gratuze, B., Haidar-Boustani, M., Ibáñez, J.J., Teira, L., 2013. Results of geochemical analyses of obsidian artefacts from the Neolithic site of Tell Labwe South, Lebanon. In: Borrell, F., Ibáñez, J.J., Molist, M. (Eds.), Stone Tools in Transition: From Hunter-Gatherers to Farming Societies in the Near East. Bellaterra, Barcelona: Universitat Autònoma de Barcelona, pp. 475494.

Khalidi, L., Gratuze, B., Stein, G., McMahon, A., Al-Quntar, S., Carter, R., Cuttler, R., Drechsler, P., Healey, E., Inizan, M.-L., Mouralis, D., Pernicka, E., Robin, A.-K., 2016. The growth of early social networks: New geochemical results of obsidian from the Ubaid to Chalcolithic Period in Syria, Iraq and the Gulf. J. Archaeol. Sci. Reports 9, 743-757.

Kintigh, K.W., 1989. Sample size, significance, and measures of diversity. In: Leonard, R.D., Jones, G.T. (Eds.), Quantifying Diversity in Archaeology, Cambridge University Press, Cambridge, pp. 25-36.

Kobayashi, K. 2006. A Study on Urban Formation in Eastern Ancient Turkey - Three Thousand Years BC. 古代トルコ東部における都市形成に関する研究 - 紀元前三千年期. In Japanese. Daelin Foundation Research Grant Implementation Report. Available at: http://www.obayashifoundation.org/app/wp-content/uploads/library_post/file163.pdf.

Kobayashi, K., Mochizuki, A., 2007. Source identification of obsidian projectile points from KamanKalehöyük. Anatolian Archaeological Studies XVI. Kaman-Kalehoyuk 16, 177-182.

Kobayashi, K., Sagona, A., 2007. A survey of obsidian sources in the provinces of Erzurum, Erzincan, Rize and Bitlis 2006. Arastirma Sonuçları Toplantısı 25, 185-196.

Kuhn, S.L., Dinçer, B., Balkan-Atlı, N., Erturaç, M.H., 2015. Paleolithic occupations of the Göllü Dağ, Central Anatolia, Turkey. J. Field Archaeol. 40, 581-602.

Maeda, O., 2003. Prehistoric obsidian distribution in the Rouj Basin. In: Iwasaki, T., Tsuneki, A. (Eds.), Archaeology in the Rouj Basin Volume 1: Regional Study of the Transition from Village to City in Northwest Syria. University of Tsukuba, Tsukuba, pp. 167-184.

Maeda, O., 2009. The Materiality of Obsidian and the Practice of Obsidian Use in the Neolithic Near East. Unpublished Ph.D. thesis, University of Manchester.

Maeda, O., 2013. Cultural affinities and the use of lithics during the 8th to 7th millennia cal. BCE in the northern Levant and Mesopotamia. In: Nieuwenhuyse, O., Bernbeck, R., Akkermans, P.M.M.G., Rogash, J. (Eds.), Interpreting the Late Neolithic of Upper Mesopotamia. Brepols, Turnhout, pp. 267-276.

Milić, M., 2014. PXRF characterisation of obsidian from central Anatolia, the Aegean and central Europe. J. Archaeol. Sci. 41, 285-296.

Milić, M., 2016. A question of scale? Connecting communities through obsidian exchange in the Neolithic Aegean, Anatolia and Balkans. In: Molloy, B. (Ed.), Of Odysseys and Oddities: Scales 
and Modes of Interaction Between Prehistoric Aegean Societies and Their Neighbours. Oxbow Books, Oxford, pp. 97-122.

Milić, M., Brown, K., Carter. T., 2013. A visual characterisation of the Çatalhöyük obsidian. In: Hodder, I. (Ed.) Substantive Technologies at Çatalhöyük: Reports from the 2000-2008 Seasons. Çatalhöyük Research Project Vol. 9. Cotsen Institute of Archaeology Press, Los Angeles, Appendix 21.1, pp. 1-7.

Nazaroff, A.J., Prufer, K.M., Drake, B.L., 2010. Assessing the applicability of portable X-ray fluorescence spectrometry for obsidian provenance research in the Maya lowlands. J. Archaeol. Sci. 37, 885-895.

Notroff, J., Dietrich, O., Schmidt, K., 2015. Gathering of the dead? The early Neolithic sanctuaries of Göbekli Tepe, southeastern Turkey. In: Renfrew, C., Boyd, M.J., Morley, I. (Eds.), Death Rituals, Social Order and the Archaeology of Immortality in the Ancient World: "Death Shall Have No Dominion." Cambridge University Press, Cambridge, pp. 65-81.

Orange, M., Carter, T., Le Bourdonnec, F.-X., 2013. Sourcing obsidian from Tell Aswad and Qdeir 1 (Syria) by SEM-EDS and EDXRF: methodological implications. Comptes Rendus Palevol 12, 173-180.

Orange, M., Le Bourdonnec, F.-X., Bellot-Gurlet, L., Lugliè, C., Dubernet, S., Bressy-Leandri, C., Scheffers, A., Joannes-Boyau, R., 2017. On sourcing obsidian assemblages from the Mediterranean area: analytical strategies for their exhaustive geochemical characterisation. J. Archaeol. Sci. Reports 12, 834-844.

Ortega, D., Ibáñez, J.J., Campos, D., Khalidi, L., Méndez, V., Teira, L., 2016. Systems of interaction between the first sedentary villages in the near east exposed using agent-based modelling of Obsidian exchange. Systems 4, 18. doi:10.3390/systems 4020018.

Ortega, D., Ibañez, J.J., Khalidi, L., Méndez, V., Campos, D., Teira, L., 2014. Towards a multi-agentbased modelling of obsidian exchange in the Neolithic Near East. J. Archaeol. Method and Theory 21, 461-485.

Orton, C., 2000. Sampling in Archaeology. Cambridge University Press, Cambridge.

Özgüç T. 1996. An obsidian storehouse close to the temples built by Anitta, King of Neša. In: Gasche, H, Hrouda, B. (Eds.), Collectanea Orientalia. Histoire, Arts de l'Espace et Industrie de la Terre. Etudes offertes en homage à Agnès Spycket. Recherches et Publications, Neuchatel-Paris, pp. 279-283.

Poupeau, G., Delerue, S., Carter, T. Perieira, C.E. de B., Miekeley N., Bellot-Gu rlet, L., 2005. How homogeneous is the 'East Göllü Dağ' (Cappadocia Turkey) Obsidian 'Source' Composition? Bull. Int. Ass. Obsidian St. 32, 3-8.

Poupeau, G., Le Bourdonnec, F.-X., Dubernet, S., Scorzelli, R.B., Duttine, M., Carter,T., 2007. Tendances actuelles dans la caractérisation des obsidiennes pour les études de provenance. ArchéoSciences 31, 79-86.

Renfrew, C., 1970. Tell Shimshara and the traffic in obsidian. In: Mortensen, P. (Ed.), Tell Shimshara: The Hassuma Period. Munksgaard, Copenhagen, pp. 139-142.

Renfrew, C., 1975. Trade as action at a distance: questions of integration and communication. In: Sabloff, J.A., Lamberg-Karlovsky, C.C. (Eds.), Ancient Civilization and Trade. University of New Mexico Press, Albuquerque, pp. 3-59.

Renfrew, C., 1977. Alternative models of exchange and spatial distribution. In: Earle, T.K., Ericson, J.E. (Eds.), Exchange Systems in Prehistory. Academic Press, London, pp. 71-90.

Renfrew, C., Dixon, J.E., Cann, J.R., 1966. Obsidian and early cultural contact in the Near East. Proc. Prehist. Soc. 32, 30-72.

Renfrew, C., Dixon, J.E., Cann, J.R., 1968. Further analysis of Near Eastern obsidians. Proc. Prehist. Soc. 34, 319-333.

Renfrew, C., 1969. The obsidian from Ali Kosh and Tepe Sabz. In: Hole, F., Flannery, K.V., Neely, J.A. (Eds.), Prehistory and Human Ecology of the Deh Luran Plain. An Early Village Sequence from Khuzistan, Iran. Museum of Anthropology, University of Michigan, Ann Arbor, Appendix 3, pp. 429-433. 
Renfrew, C., 1977. The later obsidian of Deh Luran: the evidence of Chogha Sefid. In: Hole, F. (Ed.) Studies in the Archaeological History of the Deh Luran Plain. Museum of Anthropology, University of Michigan, Ann Arbor, pp. 289-311.

Rhode, D., 1988. Measurement of archaeological diversity and the sample-size effect. Am. Antiq. 53, 708-716. doi:10.2307/281114

Robin, A.-K., Mouralis, D., Akköprü, E., Gratuze, B., Kuzucuoğlu, C., Nomade, S., Pereira, A., Doğu, A.F., Erturaç, K., Khalidi, L., 2016. Identification and characterisation of two new obsidian subsources in the Nemrut volcano (Eastern Anatolia, Turkey): the Sicaksu and Kayak obsidian. J. Archaeol. Sci. Reports 9, 705-717.

Robin, A.-K., Mouralis, D., Kuzucuoğlu, C., Akköprü, E., Gratuze, B., Doǧu, A.F., Erturaç, K., Cétoute, J., 2015. Les affleurements d'obsidiennes du Nemrut (Anatolie orientale): mise en évidence d'une source exploitable, premiers résultats. Géomorphologie: relief, processus, environnement 21, 217-234.

Robinson, D. 2004. The mirror of the sun: surface, mineral applications and interface in Californian rock art. In: Boivin, N., Owoc, M.A. (Eds.), Soils, Stones and Symbols. Cultural Perceptions of the Mineral World. Routledge, London and New York, pp 91-105.

Schechter, H., Marder, O., Barkai, R., Getzov, N., Gopher, A., 2013. The obsidian assemblage from Neolithic Hagoshrim, Israel: pressure technology and cultural influence. In: Borrell, F., Ibáñez, J.J., Molist, M. (Eds.), Stone Tools in Transition: From Hunter-Gatherers to Farming Societies in the Near East. Bellaterra, Barcelona: Universitat Autònoma de Barcelona, pp. 509-528.

Scheiber, L.L., Finley, J.B., 2011. Obsidian source use in the Greater Yellowstone Area, Wyoming Basin, and Central Rocky Mountains. Am. Antiq. 76, 372-394.

Shackley, M.S., 2008. Archaeological petrography and the archaeometry of lithic materials. Archaeometry 50, 194-215.

Sparks, R.T., 2007. Stone Vessels in the Levant. Maney, Leeds.

Speakman, R.J., Shackley, M.S., 2013. Silo science and portable XRF in archaeology: a response to Frahm. J. Archaeol. Sci. 40, 1435-1443.

Stark, B.L., Hepworth, J.T., 1982. A diversity index approach to analysis of standardization in prehistoric pottery, In: Laflin, S. (Ed.), Computer Applications in Archaeology 1982. Centre for Computing and Computer Science, University of Birmingham, Birmingham, pp. 87-104.

Stout, D., 2002. Skill and Cognition in Stone Tool Production. An Ethnographic Case Study from Irian Jaya. Curr. Anthropol. 43, 693-722.

Supernant, K., 2017, Modeling Metis mobility? Evaluating least cost paths and indigenous landscapes in the Canadian west, J. Archaeol. Sci. 84, 63-73.

Taçon, P.S.C., 1991. The power of stone: symbolic aspects of stone use and tool development in western Arnhem Land. Antiquity 65, 192-207.

Topping, P., Lynott, M. (Eds.), 2005. The Cultural Landscape of Prehistoric Mines. Oxbow Books, Oxford.

Tykot, R.H., 2011. Obsidian finds on the fringes of the Central Mediterranean: exotic or eccentric exchange?, In: Vianello, A. (Ed.), Exotica in the Prehistoric Mediterranean. Oxbow Books, Oxford, pp. 33-44.

Wilke, D., 2017, Some updated quality concerns on non-destructive geochemical analysis with XRF spectrometry. Adv. Applied Sci. Res. 8(2), 90-94.

Woolley, L. 1955. Alalakh: An Account of the Excavations at Tell Atchana in the Hatay 1937-1949. The Society of Antiquaries, London.

Yalçınkaya, i., 1998., Découvertes paléolithiques en obsidieene en Anatolie orientale. In: Cauvin, M.C., Gourgaud, A., Gratuze, B., Arnaud, N., Poupeau, G., Poidevin, J.-L., Chataigner, C. (Eds.), L'Obsidienne au Proche et Moyen Orient. Du Volcan à l'Outil. Archaeopress, Oxford, pp. 235240

Yellin J., Frachtenberg F., 1992. A re-examination of Nahal Lavan obsidian. In: Waelkens, M., Herz, N., Moens, L. (Eds.), Ancient Stones: Quarrying, Trade and Provenance: Interdisciplinary Studies 
on Stones and Stone Technology in Europe and Near East from the Prehistoric to the Early Christian Period. Leuven University Press, Leuven, pp. 139-148.

Zarins, J., 1989. Ancient Egypt and the Red Sea trade: the case for obsidian in the predynastic and archaic periods. In: Leonard, A.J., Williams, B. (Eds.), Essays in Ancient Civilization Presented to Helene J. Kantor. Oriental Institute of the University of Chicago, Chicago, pp. 339-368. 


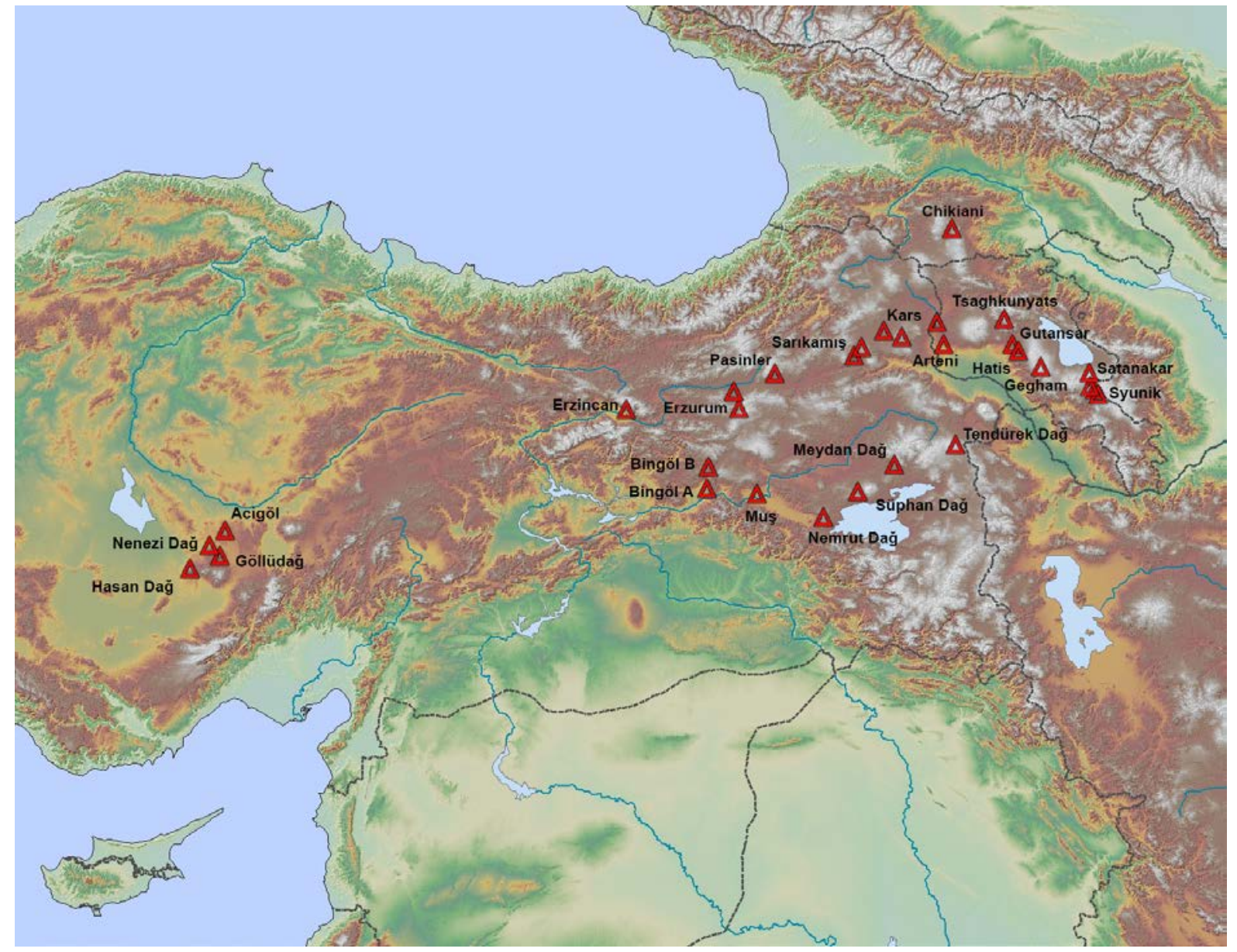

Figure 1: Map with the major obsidian sources for the Middle East. Key sources labelled. 


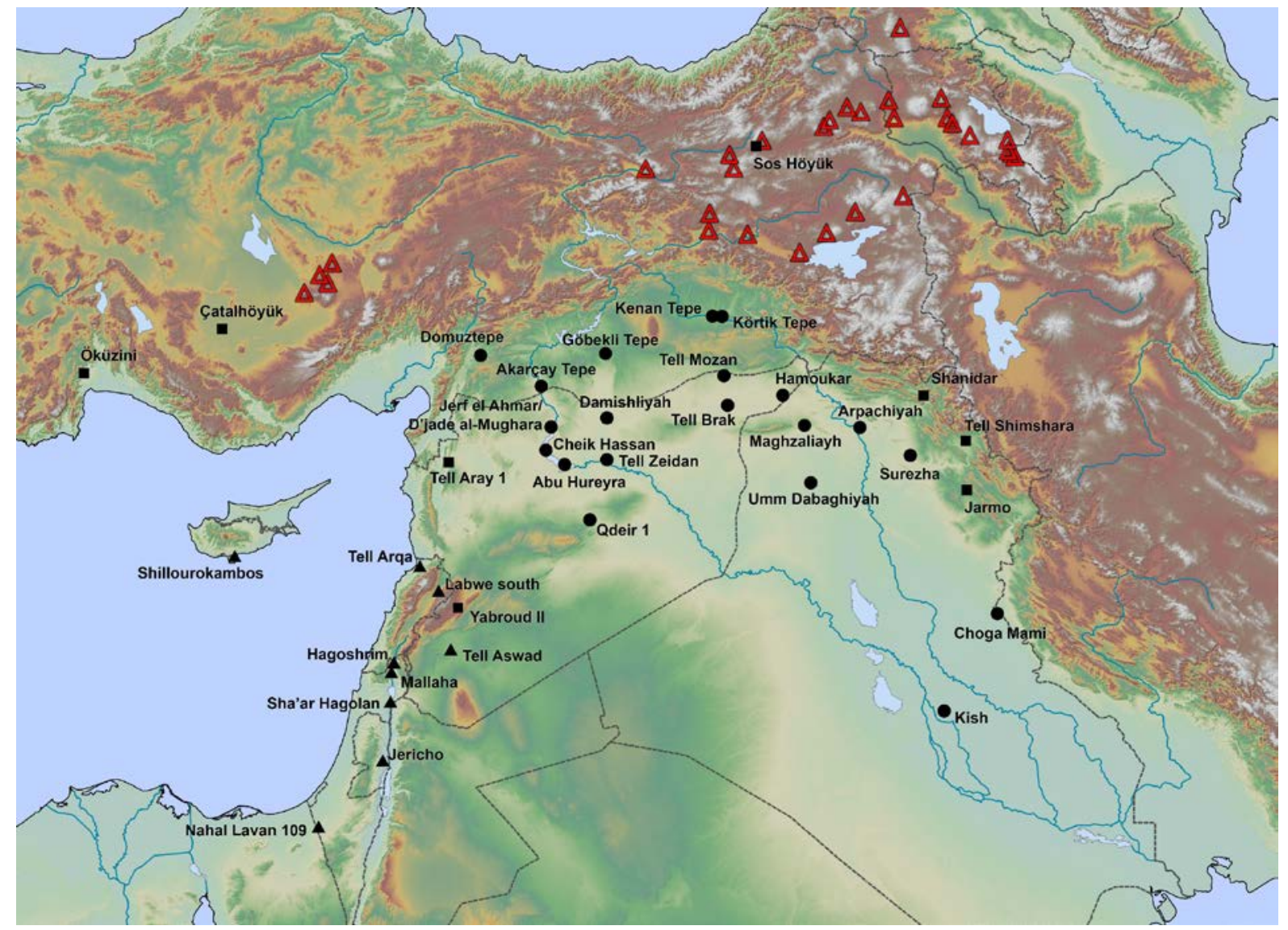

Fig. 2: Map with archaeological sites mentioned in the text (Triangles: Levantine sites with diversity indexes in Table 1; Circles: Mesopotamia sites with diversity indexes in Table 1; Squares: other sites mentioned in the text). 

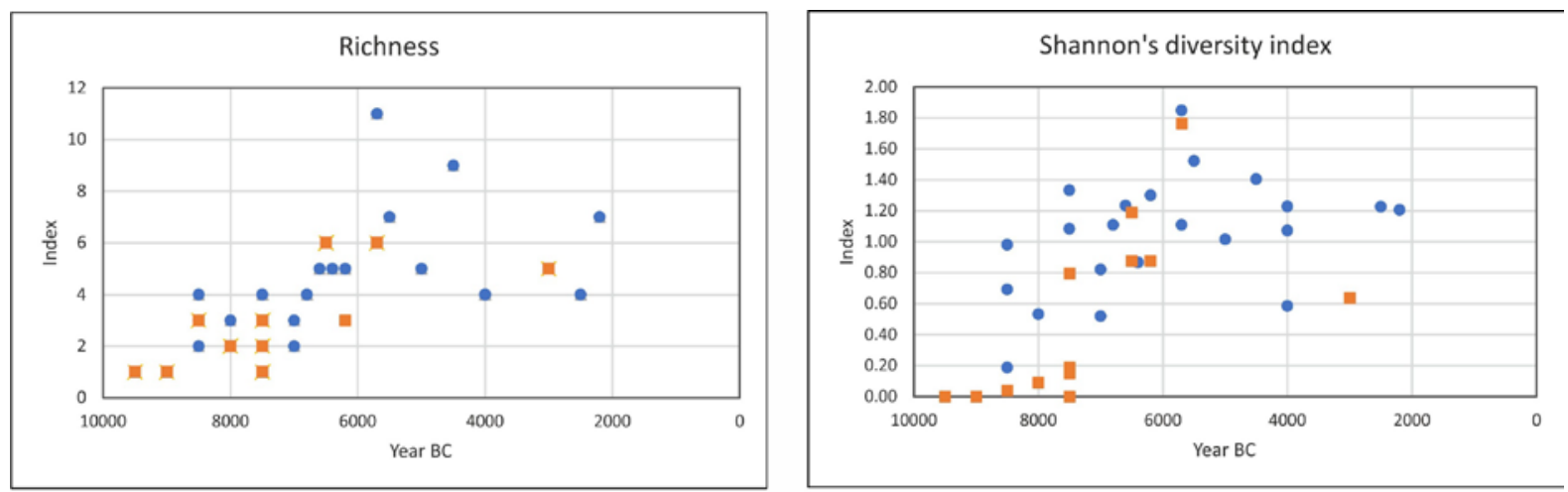

- Levant

- Mesopotamia
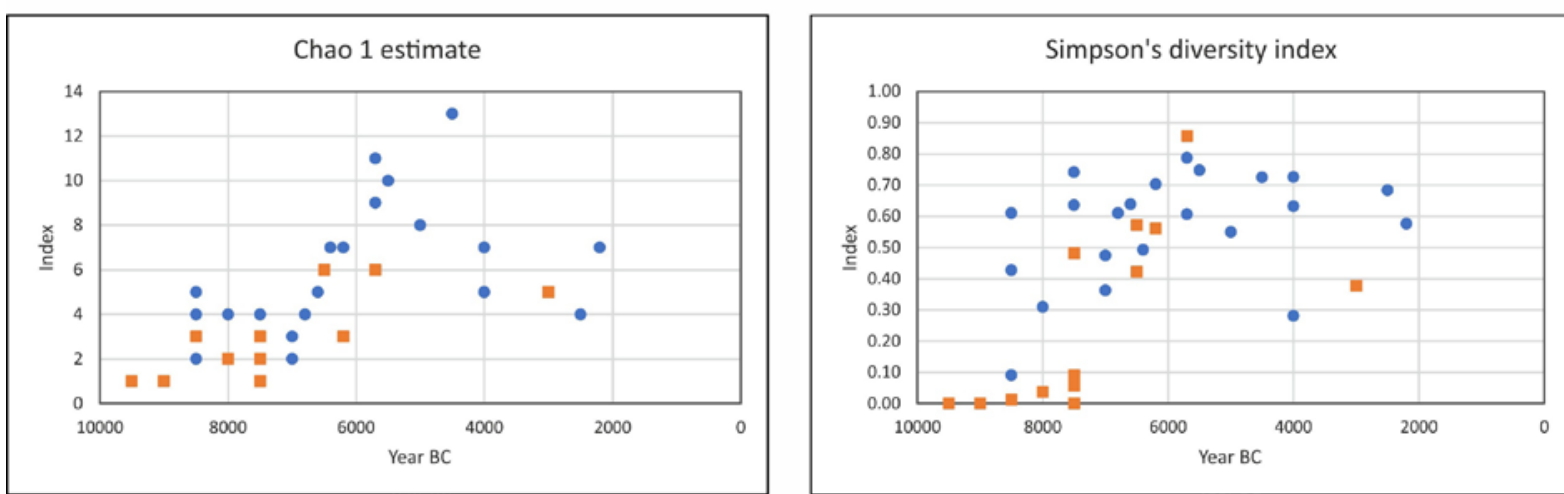

Fig. 3: Graphs showing diversity indexes for selected sites.

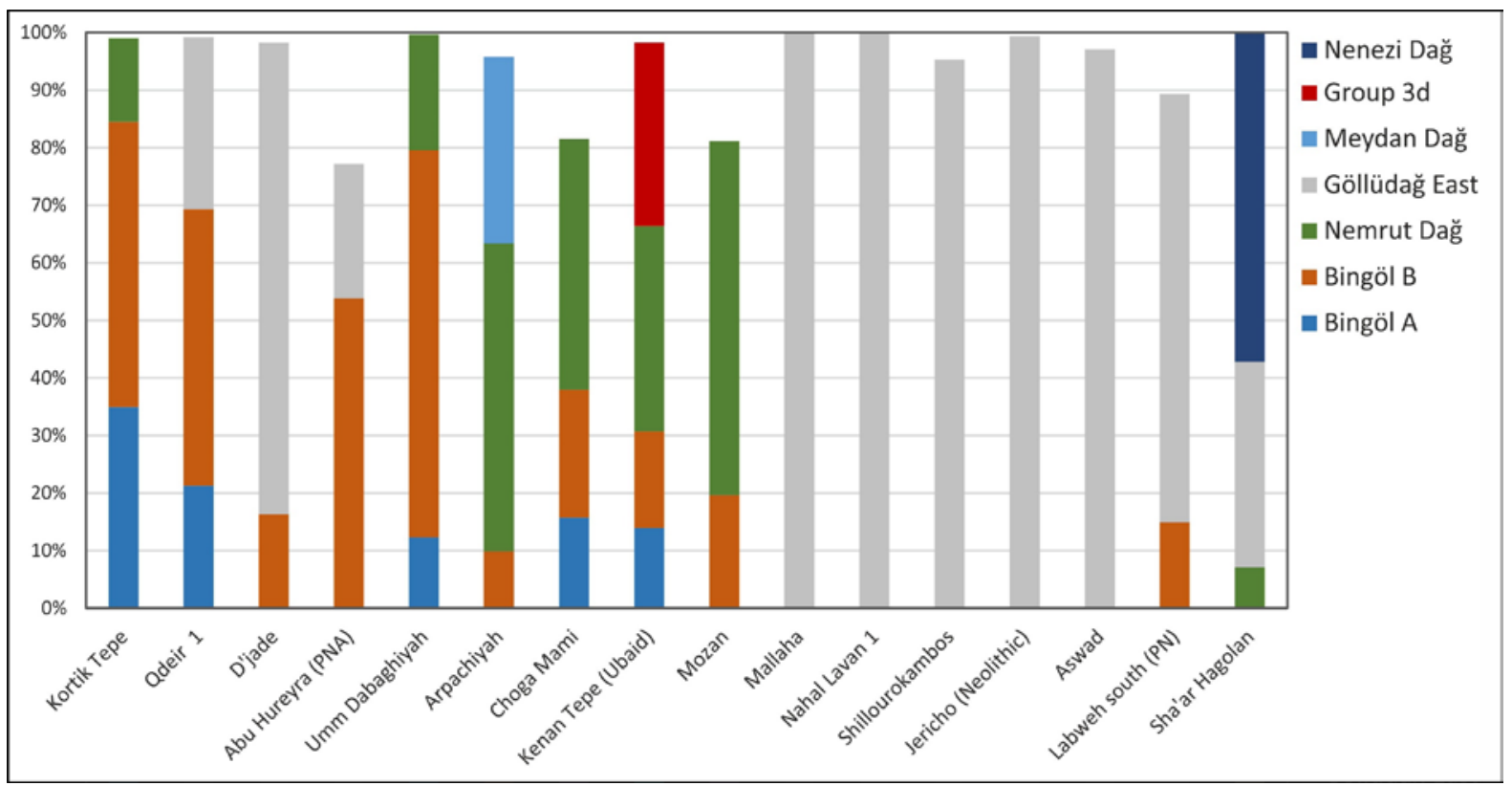

Fig. 4: Graph showing the proportions of obsidian sources that supply at least $10 \%$ of the obsidian assemblage. Selected sites, where 20-30 obsidian samples have been sourced. 


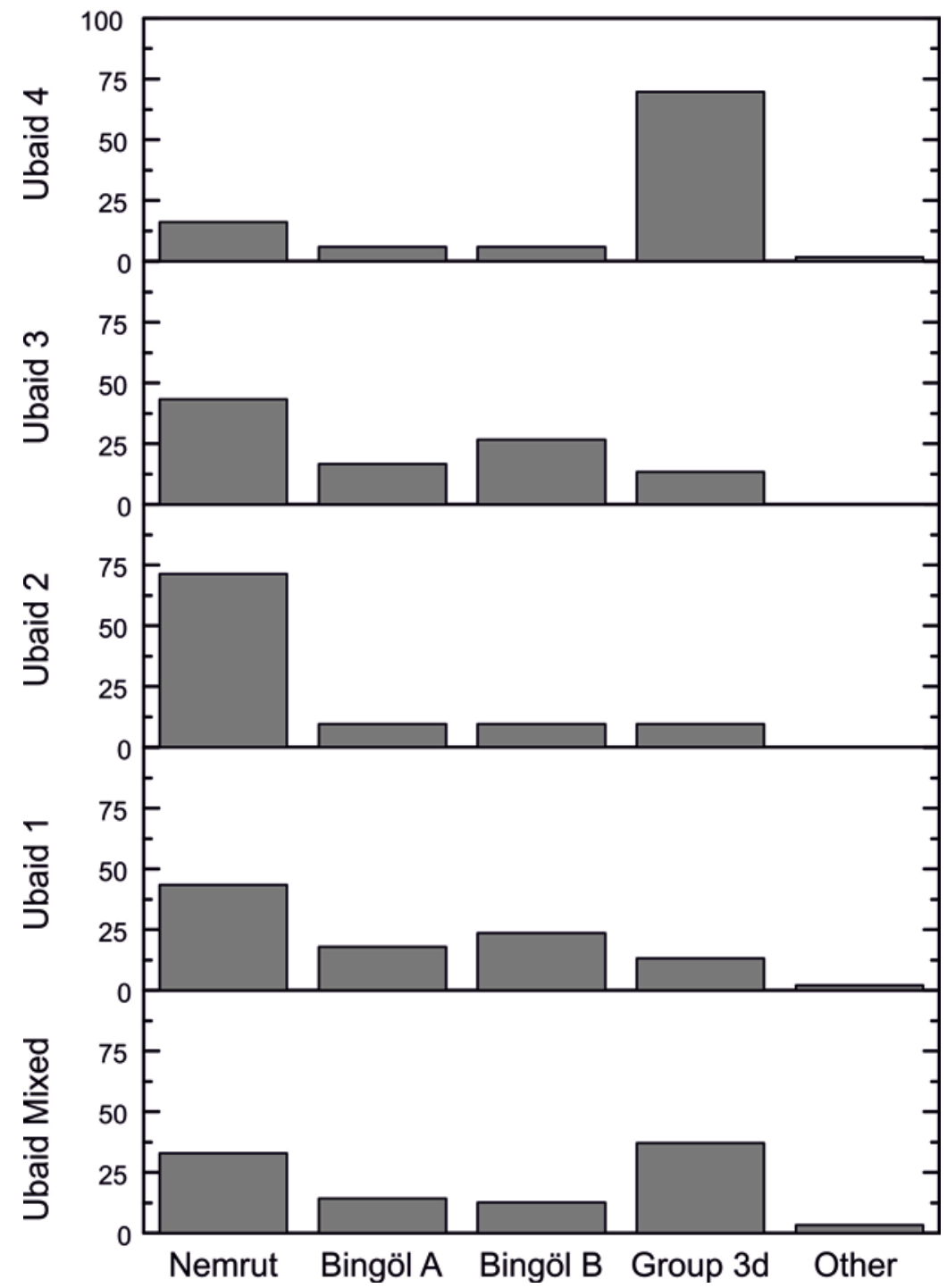

Fig. 5: Obsidian use at Kenan Tepe in the four Ubaid phases. 
Table 1: Table of diversity indexes.

\begin{tabular}{|c|c|c|c|c|c|c|c|c|}
\hline \multirow[b]{2}{*}{ Site } & \multirow[b]{2}{*}{ Region } & \multirow[b]{2}{*}{ Period } & \multirow[b]{2}{*}{ Sample } & \multicolumn{4}{|c|}{ Diversity indexes } & \multirow[b]{2}{*}{ Reference } \\
\hline & & & & Richness & $\begin{array}{l}\text { Chao } 1 \\
\text { estimate }\end{array}$ & $\begin{array}{l}\text { Shannon's } \\
\text { index }\end{array}$ & $\begin{array}{l}\text { Simpson's } \\
\text { index }\end{array}$ & \\
\hline Jerf el Ahmar & Mesop & PPNA & 43 & 2 & 2 & 0.19 & 0.09 & Abbes et al 2003 \\
\hline Körtik Tepe & Mesop & PPNA & 103 & 4 & 5 & 1.04 & 0.62 & Carter et al. 2014 \\
\hline Cheik Hassan & Mesop & PPNA & 26 & 3 & 4 & 0.69 & 0.43 & Abbes et al. 2001 \\
\hline Djade al-Mughara & Mesop & PPNA/PPNB & 55 & 3 & 4 & 0.53 & 0.31 & Bellot Gurlet 1998 \\
\hline Qdeir 1 & Mesop & PPNB & 479 & 4 & 4 & 1.08 & 0.64 & Orange et al 2013 \\
\hline Abu Hureyra & Mesop & PPNB & 45 & 4 & 4 & 1.33 & 0.74 & Carter et al. 2012 \\
\hline Damishalyah 1 & Mesop & PPNB/PN & 63 & 3 & 3 & 0.82 & 0.47 & Astruc et al. 2007 \\
\hline Akarcay Tepe & Mesop & PPNB/PN & 17 & 3 & 3 & 0.53 & 0.31 & Delerue 2007 \\
\hline Abu Hureyra & Mesop & PPNC & 25 & 4 & 4 & 1.11 & 0.61 & Carter et al. 2012 \\
\hline Abu Hureyra & Mesop & PNA & 184 & 5 & 5 & 1.23 & 0.64 & Carter et al. 2012 \\
\hline Umm Dabagiyah & Mesop & PN & 666 & 5 & 7 & 0.87 & 0.49 & Manchester Obsidian Laboratory \\
\hline Arpachiyah & Mesop & Halaf & 71 & 6 & 9 & 1.11 & 0.61 & Manchester Obsidian Laboratory \\
\hline Choga Mami & Mesop & Halaf & 54 & 7 & 9 & 1.54 & 0.74 & Epstein 1977 \\
\hline Domuztepe & Mesop & Halaf & 374 & 11 & 11 & 1.85 & 0.79 & Manchester Obsidian Laboratory \\
\hline Tell Zeidan & Mesop & Halaf-LC2 & 35 & 7 & 10 & 1.52 & 0.75 & Khalidi et al. 2016 \\
\hline Surezha & Mesop & LC1-3 & 25 & 5 & 8 & 1.01 & 0.55 & Khalidi et.al. 2016 \\
\hline Kenan Tepe & Mesop & Ubaid & 508 & 9 & 13 & 1.40 & 0.73 & Campbell and Healey 2016 \\
\hline Tell Brak & Mesop & LC3 & 28 & 4 & 5 & 1.07 & 0.63 & Khalidi et al. 2016 \\
\hline Tell Brak & Mesop & LC2 & 18 & 4 & 5 & 1.23 & 0.73 & Khalldi et al. 2016 \\
\hline Hamoukar & Mesop & LC1-2 & 33 & 4 & 7 & 0.59 & 0.28 & Khalidi et al. 2016 \\
\hline Kish & Mesop & EBA & 105 & 4 & 4 & 1.23 & 0.68 & Manchester Obsidian Laboratory \\
\hline Tell Mozan & Mesop & EBA & 244 & 7 & 7 & 1.21 & 0.58 & $\begin{array}{l}\text { Frahm 2010; Frahm \& Feinberg 2013a \& } \\
\text { 2013b }\end{array}$ \\
\hline Mallaha & Levant & Natufian & 134 & 1 & 1 & 0.00 & 0.00 & Delerue 2007; \\
\hline Jericho & Levant & $\begin{array}{l}\text { Proto- } \\
\text { Neoltihic }\end{array}$ & 36 & 1 & 1 & 0.00 & 0.00 & Manchester Obsidian Laboratory \\
\hline Jericho & Levant & PPNA & 340 & 3 & 5 & 0.04 & 0.01 & Manchester Obsidian Laboratory \\
\hline Jericho & Levant & PPNA/B & 54 & 2 & 3 & 0.09 & 0.04 & Manchester Obsidian Laboratory \\
\hline Jericho & Levant & PPNB & 51 & 1 & 1 & 0.00 & 0.00 & Manchester Obsidian Laboratory \\
\hline Tell Aswad & Levant & PPNB & 103 & 3 & 5 & 0.15 & 0.06 & Orange et al 2013 \\
\hline Labweh south & Levant & PPNB & 23 & 3 & 3 & 0.80 & 0.48 & Khalidi et al. 2013 \\
\hline Nahal Lavan 109 & Levant & PPNB & 63 & 1 & 1 & 0.00 & 0.00 & Yellin \& Frachtenburg 1992 \\
\hline Shillourokambos & Levant & PPNB & 64 & 2 & 2 & 0.19 & 0.09 & Briois et al. 1997 \\
\hline Labweh south & Levant & PN & 141 & 6 & 6 & 0.88 & 0.42 & Khalidi et al. 2013 \\
\hline Tell Arqa & Levant & PN & 31 & 6 & 10 & 1.19 & 0.57 & Khalidi et al. 2013 \\
\hline Hagoshrim & Levant & Halaf & 25 & 6 & 6 & 1.76 & 0.86 & Schechter et al. 2013 \\
\hline Jericho & Levant & $\begin{array}{l}\text { Post- } \\
\text { Neolithic }\end{array}$ & 10 & 5 & 9 & 0.64 & 0.38 & Manchester Obsidian Laboratory \\
\hline
\end{tabular}

